Review Paper

\title{
A review on advances in doping with alkali metals in halide perovskite materials
}

\author{
Madeeha Tabassum $^{1} \cdot$ Qasim Zia $^{2} \mathbb{D} \cdot$ Yongfeng Zhou $^{1} \cdot$ Michael J. Reece ${ }^{1,2} \cdot$ Lei Su$^{1}$
}

Received: 27 July 2021 / Accepted: 14 November 2021

Published online: 25 November 2021

(c) The Author(s) 2021 OPEN

\section{Abstract}

Recent progress in doping of halide perovskite materials (HPM) by using targeted elements has provided a dimension beyond structural and compositional modification, for achieving desired properties and resulting device performance. Herein doping of alkali metal ions $\left(\mathrm{Li}^{+}, \mathrm{Na}^{+}, \mathrm{K}^{+}, \mathrm{Rb}^{+}\right.$, and $\left.\mathrm{Cs}^{+}\right)$in three-dimensional HPM is reviewed to lay a particular focus on advances in synthesis, doping-induced changes in optical and electrical properties, and their optoelectronic applications. The introduction of alkali metals in HPM shows an effective route for improved morphology, suppressed ion migration, reduction in non-radiative recombination, passivation of bulk and interface defects, and increased thermal stability. In the end, we provide our perspective that the effect of alkali metal incorporation on the efficiency and stability of HPM should be further investigated via in-situ characterization methods and doped HPM should be considered for more functional applications.

\section{Graphical abstract}

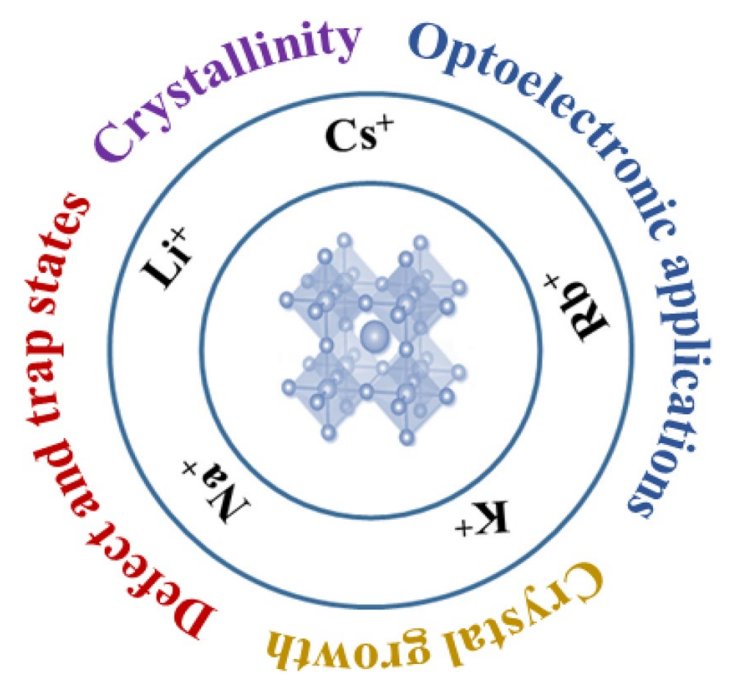

Keywords Halide perovskites · Doping · Alkali metals · Morphology · Defects · Stability

Lei Su, I.su@qmul.ac.uk | ${ }^{1}$ School of Engineering and Materials Science, Queen Mary, University of London, London E14NS, UK. ${ }^{2}$ Department of Materials, The University of Manchester, Oxford Rd, Manchester M13 9PL, UK. 


\section{Introduction}

Halide perovskite materials (HPM) have emerged as a class of excellent semiconductors in high-performance optoelectronic applications. In 1839, the term "perovskite" was first coined by Gustav Rose for the $\mathrm{CaTiO}_{3}$ mineral, who named it after nobleman Count Lev Alekseyevich von Perovski. These materials demonstrate unique optical and electrical properties such as tunable bandgap, high photoluminescence quantum yields (PLQYs), high light absorption coefficient, and efficient charge carrier mobility, hence could exhibit a promising future for next-generation electronic devices [1, 2]. The potential to combine all the listed properties in one material with low-cost solution processability has emerged HPM as a focus of current research. In recent years, perovskite materials have been used as a functional layer in light-emitting diodes (LEDs) with external quantum efficiency (EQE) up to $28.2 \%$ [3], highly sensitive photodetectors with low noise in photon detections, lasers with an ultralow lasing threshold of $220 \mathrm{~nJ} /$ $\mathrm{cm}^{2}$, and perovskite solar cells (PSCs) achieving certified power conversion efficiency (PCE) of $25.5 \%$ [4-6]. Such remarkable performance of perovskite materials has been made possible by the general perovskite structure $A B X_{3}$, where $A$ is monovalent cation (that can be either organic (e.g., $\mathrm{CH}_{3} \mathrm{NH}_{3}{ }^{+}$(methylammonium/MA ${ }^{+}$), $\mathrm{CH}\left(\mathrm{NH}_{2}\right)_{2}{ }^{+}$(formamidinium/ $\left.\mathrm{FA}^{+}\right)$) or inorganic e.g., $\mathrm{Cs}^{+}$ (cesium)), $\mathrm{B}$ is a divalent cation mostly $\mathrm{Pb}^{2+}$ (lead), $\mathrm{Sn}^{2+}$ (tin) and $\mathrm{Bi}^{3+}$ (bismuth) or their co-alloying with $\mathrm{Ge}^{2+}$ (germanium) and $\mathrm{Mn}^{2+}$ (manganese), and $\mathrm{X}$ is a halide anion $\left(\mathrm{Cl}^{-}, \mathrm{Br}^{-}, \mathrm{I}^{-}\right.$or their mixtures) [7-9]. The crystal structure of $\mathrm{ABX}_{3}$ type perovskite consists of a network of corner-shared lead halide octahedra $\left[\mathrm{BX}_{6}\right]^{-4}$ with a 12-fold coordinated large size A-site cation fulfilling the voids to balance the charge. These materials can form multiple structural polymorphs from cubic to hexagonal complex phase depending on the connectivity to the $\left[\mathrm{BX}_{6}\right]^{-4}$ octahedra [10-12]. HPM with such unique structures possess excellent photoelectric properties, low exciton binding energy, and solar light absorbance [13].

Doping engineering, a method to introduce impurity atoms into the target crystal lattice can optimize the perovskite materials performance without affecting their structure and inherent properties $[14,15]$. Taking into account the inherent HPM related issues such as their long-term stability, defect states, and performance has attracted the doping strategy [16-18]. To fill these gaps, researchers [19-22] have been working on the incorporation of various ions into the HPM to study their effects. Only a small amount of dopants can modify the required characteristics of halide perovskites to the required level without introducing deep energy levels. In addition, doping elements usually do not give rise to the quenched emission due to the surface defect states as reported in conventional II-VI, III-V, and IV-VI inorganic semiconductors $[23,24]$. Therefore, the strategy to dope heteroatoms into the perovskite structure increases the ability to optimize the structural parameters and efficiency. Such as doping of A-site cation has been mostly reported to tune the bandgap, and ability to make the host perovskite more stable [25]. Moreover, B-site doping is used to reduce the toxicity of lead ions and extend the charge carrier lifetime of solar power conversion and light absorption process $[26,27]$. Furthermore, mixing of $X$-site halide anions not only serve the purpose of desired shift in absorption band but also optimizes the electro luminance (EL) spectrum of perovskites [28]. Hence, compared with pristine halide perovskites, doped HPM can improve the performances of solar cells, lasers, LEDs, photodetectors, and field-effect transistors [29].

For a stable doped perovskite structure, the ionic radii of all constituent elements should match well [30]. Notably, to predict the structural stability and lattice distortion of $\mathrm{ABX}_{3}$ type perovskite materials, the Goldschmidt tolerance factor $(T)$ has been widely used in applied studies. The $T$ is determined by the ratios of effective ionic radii of the cation $A\left(R_{A}\right)$, the cation $B\left(R_{B}\right)$, and the $X\left(R_{X}\right)$ anion using the following expression:

$T=R_{A}+R_{X} / \sqrt{ } 2\left(R_{B}+R_{X}\right)$

The perfect symmetry of perovskite compounds adopts a cubic close-packed crystal structure with $T=1$. When the value of constituent ionic radii deviates from the ideal case $(T \neq 1)$, the crystal distortion and structural strain occur. As this deviation arises, the crystal adopts a lower symmetry structure than the cubic one [31, 32]. To further describe the threshold of perovskite compounds stability, an additional octahedral factor $(\mu)$ which is the ratio of $R_{B}$ to $R_{X}$ is needed to show the structural map capable to display the formability of perovskites [33-35].

Recent research on doping halide perovskites with alkali metal ions such as $\mathrm{Li}^{+}, \mathrm{Na}^{+}, \mathrm{K}^{+}, \mathrm{Rb}^{+}$, and $\mathrm{Cs}^{+}$has been acknowledged for polycrystalline and nanocrystalline thin films to maximize structural and optoelectronic properties i.e. to maximize luminance, facilitates charge injection, enhanced moisture resistance, and energy band alignment [36-38].

In this comprehensive review, we discussed advances in the doping of alkali metals for 3D $\mathrm{ABX}_{3}$ type HPM, which are divided into two sections based on their polycrystalline and nanocrystalline nature. In detail, this review summarizes the impact of alkali metal ions on charge carrier dynamics, crystallinity, bulk and interface defects, and 
their ability to influence optoelectronic device properties of HPM. Furthermore, a brief outlook about unresolved issues is also reviewed.

\section{Influence of cesium ions doping in HPM}

To date, cesium (Cs) is the only alkali metal that can substitute $A$-site cation in $\mathrm{ABX}_{3}$ type perovskites due to its large ionic radii $(1.67 \AA)[39,40]$. Mixing of $C$ s ions with other A-site cations $\left(\mathrm{MA}^{+}, \mathrm{FA}^{+}\right)$is considered as a milestone to address the problem of structural instability, thermal and moisture sensitivity of halide perovskite devices [41-43]. Among all HPM light harvesters, methylammonium lead triiodide $\left(\mathrm{MAPbl}_{3}\right)$ and formamidinium lead triiodide $\left(\mathrm{FAPbl}_{3}\right)$ have been considered as champion compounds in recent years due to their exceptional absorption coefficient, low exciton binding energy, and excellent photovoltaic properties. However, $\mathrm{MAPbl}_{3}$ shows disturbing phase transition (tetragonal-cubic) at about $56^{\circ} \mathrm{C}$, while the operating temperature of solar cells is approximately $85^{\circ} \mathrm{C}$. Also, the bandgap of $\mathrm{MAPbl}_{3}$ is $1.57 \mathrm{eV}$, which hinders the absorption of solar light above $800 \mathrm{~nm}$ and ultimately reduces the efficiency of PSCs. Although thermally stable $\mathrm{FAPbl}_{3}$ with an appropriate bandgap of $1.48 \mathrm{eV}$ shows potential in the presence of sunlight, however, its photoactive a-phase (black phase) transformation into undesired nonphotoactive $\delta$-phase (yellow phase) at room temperature is a big issue $[40,44,45]$. Therefore, optimization of a photovoltaic device efficiency is challenging while using a single cation and it has been suggested to modify the perovskites by mixing of Cs-MA, Cs-FA or CsFA-MA cations $[46,47]$.

The incorporation of $\mathrm{Cs}$ ions into the $\mathrm{FAPbl}_{3}$ perovskite system improves the phase stability, particularly its transformation from black to yellow phase $[48,49]$. A report was published for stabilization of a phase of $\mathrm{FAPbl}_{3}$, where a computational study was performed to check the influence of $\mathrm{FA}^{+}$cation substitution with monovalent cation $\mathrm{MA}^{+}, \mathrm{Cs}^{+}$, and $\mathrm{Rb}^{+}$. A series of simulation were performed for relative stabilization of a with respect to $\delta$ phase as a function of chemical nature of the dopant, doping amount, and temperature. It was suggested that a perovskite phase of $\mathrm{FAPbl}_{3}$ can be best stabilized at ambient temperature by $42-50 \%$ of mixed $\mathrm{Cs} / \mathrm{Rb}$ doping and $\mathrm{MA}^{+}$can be avoided as it is directed to make the a phase less stable. Furthermore, the substitution of these alkali ions into the target system blue shift the onset of optical spectra by $0.1-0.2 \mathrm{eV}$ with respect to pristine $\mathrm{FAPbl}_{3}$ This study paves the way towards the replacement of organic cation with $\mathrm{Cs}$ and $\mathrm{Rb}$ ions which are efficient in stabilizing its photoactive phase [38]. In a recent study, two-step spin coating for sequential doping of Cs and GA (guanidinium) cations was adopted to demonstrate the control on crystallization kinetics of $\mathrm{FAPbl}_{3}$ perovskite thin film with an average grain size of $\approx 300 \mathrm{~nm}$ for solar cell application. The addition of Cs cations in the first step induces the formation of $\delta-\mathrm{CsPbl}_{3}$ which provides an alternative phase transition pathway for perovskite a-phase. However, slightly larger crystalline grains of about $600 \mathrm{~nm}$ with several pinholes are formed due to nonuniform nucleation by sparse $\delta-\mathrm{CsPbl}_{3}$ crystals. This problem is solved in the second step where doping of GA cations eliminates the pinholes and further enhanced grain boundaries of $\approx 1 \mu \mathrm{m}$, hence solar cell device efficiencies above $23 \%$ were recorded [50]. Another study was reported about the addition of cesium chloride $(\mathrm{CsCl})$ in mixed cation formulation of $\mathrm{FA}_{0.80} \mathrm{Cs}_{0.20} \mathrm{Pbl}_{3}$ results in highquality photoactive layer, large grain size $(\approx 1 \mu \mathrm{m})$, longer carrier lifetime (108.4 ns), with perovskite solar cell devices showed PCE of $19.85 \%$ [51].

It is now well established from a variety of studies [52-56] that the doping of Cs ions into $\mathrm{MAPbX}_{3}$ perovskites optimizes the optical and electrical parameters of the materials while retaining their fundamental properties. Guangcheng and Rui claimed that doping of $\mathrm{Cs}$ into the $\mathrm{MAPbl}_{3-\mathrm{x}} \mathrm{Cl}_{x}$ perovskite films enhances the grain morphology, lifts the valence and conduction band edges, passivate the trap states, and hence promote the flow of charge carriers [57].

Most importantly, the HPM among which the mixed cation (FAMA) perovskites showed many outstanding properties such as improved carrier diffusion length, broad absorption spectrum give rise the solar power conversion efficiency over $22 \%[58,59]$. According to recent studies, partial replacement of FA with smaller size cations $\left(\mathrm{MA}^{+}, \mathrm{Cs}^{+}\right.$, and $\left.\mathrm{Rb}^{+}\right)$can be the most suitable strategy to work with photoelectric characteristics of FAMA mixed cation perovskites. Shihao et al. treated mixed cation $\mathrm{FA}_{0.85} \mathrm{MA}_{0.15} \mathrm{Pbl}_{3}$ with cesium acetate (CsAc) and doped perovskite films exhibited a large grain size of about $1.39 \mu \mathrm{m}$ ( Fig. 1a), longer carrier lifetime of $61.5 \mathrm{~ns}$ is benefited from the reduction in trap assisted recombination (Fig. 1b). The maximum PCE of $21.95 \%$ and $97 \%$ retention in initial PCE values after aging for 55 days was recorded after alloying with $\mathrm{Cs}^{+}$and $\mathrm{Ac}^{-}$(Fig. 1c, Table 1) [60]. After that, Bowen claimed highest reported PCE (22.81\%) of PSCs based on four components $\mathrm{Rb}_{\mathrm{x}} \mathrm{Cs}_{\mathrm{x}}\left(\mathrm{MA}_{(1-2 \mathrm{x}) / 2}\right.$ $\left.\mathrm{FA}_{(1-2 \mathrm{x}) / 2}\right) \mathrm{Pbl}_{3}$. The reason behind enhanced efficiency is controlled doping of $\mathrm{Rb}^{+}$and $\mathrm{Cs}^{+}$into the precursor solution which facilitates the transformation of $\delta$ phase into a phase, improve the photovoltaic performance (Fig. 1e, Table 1), and reduced PL lifetimes from $115 \mathrm{~ns}$ to 90 and 30 ns for 10 and 20\% doping concentration (Fig. 1d) [61]. The most recent research studies available on alkali doped HPM for photovoltaic applications are summarized in Table 1. 
(a)
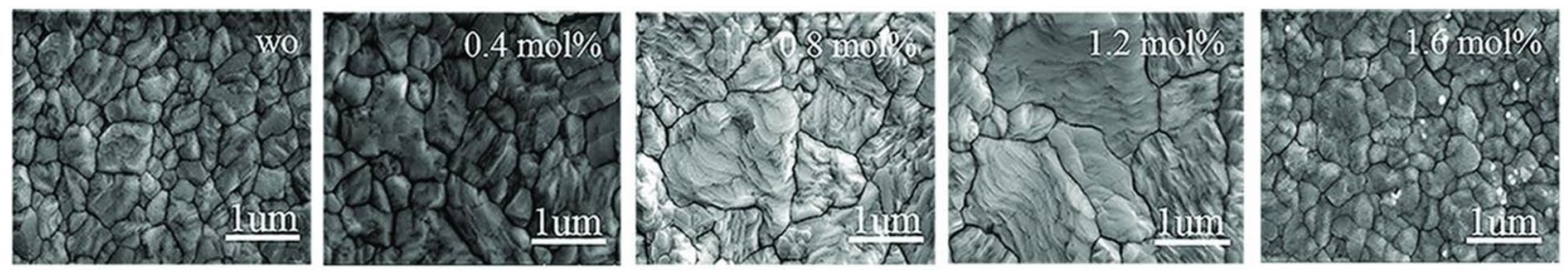

(b)

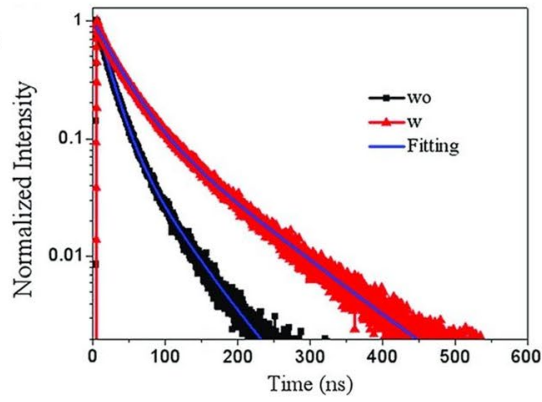

(d)

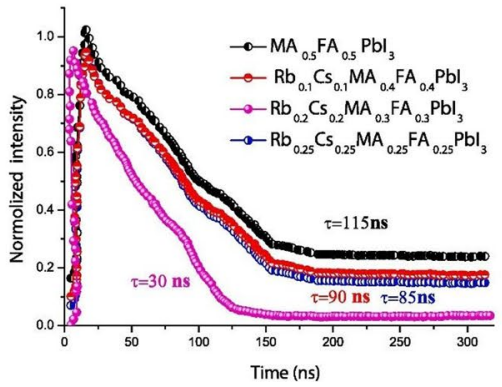

Fig. 1 a SEM images of perovskite films deposited on FTO substrates with $0,0.4,0.8,1.2$, and $1.6 \mathrm{~mol} \% \mathrm{CsAc}$ alloying (left-right). b Time-resolved PL of perovskite films wo/w CsAc alloying. c Stable output curves of current densities and efficiencies of the best-performing PSCs wo/w CsAc alloying. Adapted with permission from

Nanocrystalline HPM can be characterized as minimizing the exciton dissociation and increasing the radiative recombination because of the quantum confinement effect [75-77]. However, their structural stability and physicochemical-related issues may drop the efficiency of perovskite devices within a few operating hours [78, 79]. To address these issues, mixed cation $\left(\mathrm{Cs}^{+} / \mathrm{FA}^{+}\right)$based $\mathrm{FA}_{(1-\mathrm{x})} \mathrm{Cs}_{\mathrm{x}} \mathrm{PbBr}_{3}$ perovskites nanocrystals (NCs) have been prepared to study the influence of $\mathrm{Cs}$ doping on the performance of LEDs. This study also offers some important insights into the different chemical composition range (Fig. 2a) with variable ratio of $\mathrm{FA} / \mathrm{Cs}(\mathrm{x}=0-0.6)$, crystal formation, and tuning of the optical bandgap. X-ray diffraction (XRD) analysis (Fig. 2b) of all composition range of these NCs showed standard perovskites crystal phase. The peak shift from $15.01^{\circ}$ to $15.39^{\circ}$ was displayed, which shows the shrinkage of d-spacing due to smaller size Cs insertion into the crystal lattice (Fig. 2c). To further confirm the effect of $\mathrm{Cs}$ doping, high-resolution transmission electron microscopy (TEM) is conducted and observe the reduction in lattice spacing and confirm the (c)

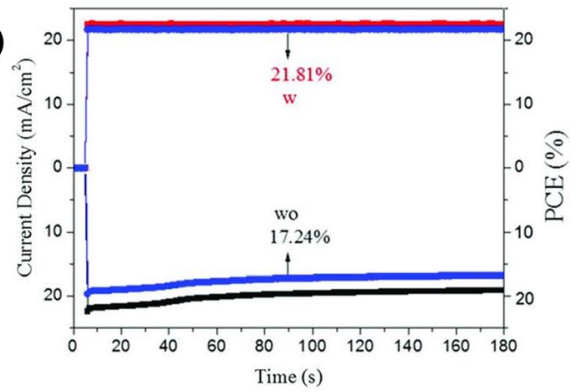

(e)

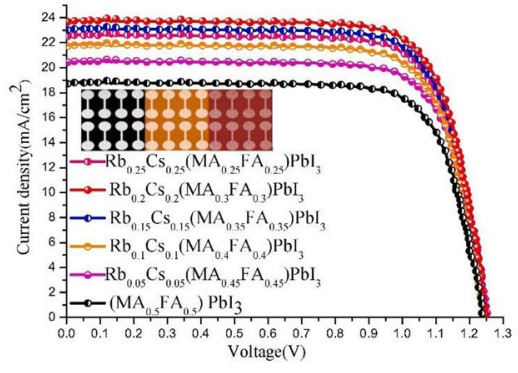

ref. [60], copyright 2019, WILEY-VCH. d Time-resolved PL e and photovoltaic performance of perovskite thin films doped with different proportion of $\mathrm{Rb}+$ and $\mathrm{Cs}+$ ions. Adapted with permission from ref.[61], copyright 2020, Elsevier

presence of smaller size Cs cation. All the perovskite NCs crystallize with the cubic shape and a negligible effect was observed on their sizes after Cs doping. As the content of Cs increases, a blue shift in absorption band from 525 to $503 \mathrm{~nm}$ (Fig. 2a), corresponds to a shift in bandgap towards high energy levels from 2.27 to $2.33 \mathrm{eV}$. Moreover, the PL peak (Fig. 2e) was finely tuned from 531 to $519 \mathrm{~nm}$, with varying ratios of $\mathrm{Cs}$ cation doping. Finally, Fig. $2 \mathrm{f}-\mathrm{i}$ and Table 2 show the overview of current density to voltage $(J-V)$ characteristics of LEDs based on FA ${ }_{(1-x)} \mathrm{Cs}_{x} \mathrm{PbBr}_{3}$. The best efficiency is achieved when $x=0.2$ with maximum luminance $55,005 \mathrm{cdm}^{-2}$, the current efficiency of $10.09 \mathrm{~cd} \mathrm{~A}^{-1}$, and EQE of $2.80 \%$ [80].

The approach used in this study was also reported by Bin $X u$ et al., to support the stance of commercialization of perovskites LEDs [88]. The ligand-assisted reprecipitation (LARP) technique was used to prepare colloidal $\mathrm{MA}_{1-x} \mathrm{Cs}_{x} \mathrm{PbBr}_{3}$ $\mathrm{NCs}$ with the varying amount $(\mathrm{x}=0-0.4)$ of $\mathrm{Cs}$ doping in the mixed cation. The precursor solution was prepared by dissolving $\mathrm{MABr}, \mathrm{CsBr}, \mathrm{PbBr}_{2}$, oleic acid and oleylamine and in 
Table 1 Summary of alkali metal ions doped perovskite solar cell performance

\begin{tabular}{|c|c|c|c|c|c|c|}
\hline Perovskite active layer & Doped alkali metal & $\mathrm{V}_{\mathrm{OC}}[\mathrm{V}]$ & $\mathrm{J}_{\mathrm{sc}}[\mathrm{mA} / \mathrm{cm} 2]$ & $\mathrm{FF}[\%]$ & PCE [\%] & Ref. \\
\hline CsMAFAPbl $_{3-\mathrm{x}} \mathrm{Br}_{\mathrm{x}}$ & $\mathrm{Rb}$ & 1.18 & 22.80 & 81.00 & 21.80 & {$[62]$} \\
\hline MAFAPbl $_{3-x} \mathrm{Br}_{\mathrm{x}}$ & $\mathrm{Rb}$ & 1.125 & 23.24 & 71.90 & 18.80 & [63] \\
\hline$(\mathrm{Cs}, \mathrm{FA}, \mathrm{MA}) \mathrm{Pb}\left(\mathrm{I}_{0.85} \mathrm{Br}_{0.15}\right)_{3}$ & $\mathrm{~K}$ & 1.17 & 23.20 & 79.00 & 21.50 & {$[64]$} \\
\hline $\mathrm{FA}_{0.83} \mathrm{MA}_{0.17} \mathrm{~Pb}\left(\mathrm{I}_{0.83} \mathrm{Br}_{0.17}\right)_{3}$ & $\mathrm{~K}$ & 1.15 & 23.50 & 75.00 & 20.40 & [65] \\
\hline $\mathrm{MA}_{0.17} \mathrm{FA}_{0.83} \mathrm{~Pb}\left(\mathrm{I}_{0.83} \mathrm{Br}_{0.17}\right)_{3}$ & $\mathrm{Rb}$ & 1.16 & 22.80 & 78.00 & 21.00 & [66] \\
\hline $\mathrm{CsPbl}_{2} \mathrm{Br}$ & $\mathrm{Rb}$ & 1.24 & 14.02 & 69.00 & 12.00 & {$[67]$} \\
\hline $\mathrm{CsPbl}_{2} \mathrm{Br}$ & $\mathrm{Rb}$ & 1.32 & 16.25 & 80.03 & 17.16 & [68] \\
\hline \multirow[t]{2}{*}{$\mathrm{FA}_{0.83} \mathrm{MA}_{0.17} \mathrm{~Pb}\left(\mathrm{I}_{0.83} \mathrm{Br}_{0.17}\right)_{3}$} & $\mathrm{Rb}$ & 1.14 & 19.97 & 72.00 & 16.51 & [69] \\
\hline & Cs & 1.16 & 20.56 & 74.00 & 17.75 & \\
\hline \multirow[t]{2}{*}{$\mathrm{MAPbl}_{3}$} & $\mathrm{Na}$ & 1.10 & 21.16 & 78.00 & 18.16 & [70] \\
\hline & $\mathrm{K}$ & 1.10 & 20.88 & 78.00 & 17.81 & \\
\hline $\mathrm{FA}_{0.85} \mathrm{MA}_{0.15} \mathrm{~Pb}\left(\mathrm{I}_{0.85} \mathrm{Br}_{0.15}\right)_{3}$ & $\mathrm{~K}$ & 1.16 & 22.99 & 76.00 & 20.32 & [71] \\
\hline $\mathrm{Cs}_{0.05} \mathrm{FA}_{0.79} \mathrm{MA}_{0.16} \mathrm{~Pb}\left(\mathrm{I}_{0.6} \mathrm{Br}_{0.4}\right)_{3}$ & $\mathrm{~K}$ & 1.26 & 19.19 & 76.00 & 18.38 & {$[72]$} \\
\hline $\mathrm{CH}_{3} \mathrm{NH}_{3} \mathrm{Pbl}_{3}$ & $\mathrm{~K}$ & 0.92 & 19.07 & 68.00 & 12.07 & [73] \\
\hline $\mathrm{MAPbl}_{3-\mathrm{x}} \mathrm{Cl}_{\mathrm{x}}$ & Cs & 0.99 & 21.10 & 79.30 & 16.60 & {$[57]$} \\
\hline $\mathrm{FAPbl}_{3}$ & $\mathrm{Cs}+\mathrm{MDA}^{*}$ & 1.16 & 26.17 & 80.10 & 24.40 & [74] \\
\hline $\mathrm{FA}_{0.85} \mathrm{MA}_{0.15} \mathrm{Pbl}_{3}$ & Cs & 1.16 & 24.92 & 78.64 & 21.95 & {$[60]$} \\
\hline $\mathrm{MA}_{0.5} \mathrm{FA}_{0.5} \mathrm{Pbl}_{3}$ & $\mathrm{Cs}+\mathrm{Rb}$ & 1.25 & 23.70 & 77.00 & 22.81 & [61] \\
\hline
\end{tabular}

*Methylenediammonium dimethylformamide (DMF) and controlled amount of this solution added in anti-solvent to form green colloidal solution of perovskite NCs. The as-synthesized perovskites NCs were single-crystalline of size between 8 and $12 \mathrm{~nm}$ (Fig. 3a). To study the effect of Cs doping amount on the optical properties of mixed cation perovskite NCs, UV-Vis absorption and photoluminance (PL) spectra were recorded (Fig. 3b-c). With the different amounts of $\mathrm{Cs}$ doping, the absorption band was blue-shifted from 515 to $505 \mathrm{~nm}$ and PL spectra also changed from 539 to $533 \mathrm{~nm}$. The crystalline structure of all Cs doped samples was exhibited from XRD patterns (Fig. 3d) and the increase in (110) peak intensity shows the preferred crystal growth after the addition of dopant. The synthesized $\mathrm{MACsPbBr}_{3} \mathrm{NCs}$ were single crystalline with the sizes changing from 8 to $12 \mathrm{~nm}$ and had a cubic shape with no significant change observed after the addition of Cs ions into the samples. The J-V characteristics of optimized Cs doped perovskite LEDs showed the excellent value of luminance $24,500 \mathrm{cdm}^{-2}$ and the EQE of $1.3 \%$ (Fig. 3e-f, Table 2).

\section{Role of incorporating rubidium ions in HPM}

Rubidium ( $\mathrm{Rb}$ ) has been considered an emerging alkali metal that can be used as a functional dopant in HPM, which has a significant impact on the structural parameters of single or mixed cation perovskites [89].

The debate on whether $\mathrm{Rb}$ metal cations occupy the main A-site position in a perovskite crystal lattice or not is still controversial. However, few studies showed the presence of $\mathrm{Rb}^{+}$ions at the A-site of the perovskite crystal lattice. Saliba et al. [62] first embedded the $\mathrm{Rb}^{+}$ into the mixed A-site cation (CSMAFA) formulations to achieve stabilized PCE of $21.6 \%$. This study opens the avenue to study the influence of rubidium ions for multi cation perovskites on solar cells, LEDs and photo-detection applications. Daniel et al. [66] worked on the doping of rubidium iodide (Rbl) for state-of-the-art triple cation composition $\mathrm{Cs}_{5}\left(\mathrm{MA}_{0.17} \mathrm{FA}_{0.83}\right)_{95} \mathrm{~Pb}\left(\mathrm{I}_{0.83} \mathrm{Br}_{0.17}\right)_{3}$ synthesized in the recently published study [90]. The addition of $\mathrm{Rb}^{+}$ions to the mixed A-cation perovskite showed an improved PCE of about $21 \%$ mainly due to high opencircuit voltage (1.16 V) and fill factor (78\%). Furthermore, different concentration of Rbl (0.5-2\%) for all in-organic perovskite $\left(\mathrm{CsPbl}_{2} \mathrm{Br}\right)$ was analyzed in the construction of high-efficiency, low cost, and improved air stability of hybrid PSCs [67]. Compared with un-doped $\mathrm{CsPbl}_{2} \mathrm{Br}$ perovskite films, excellent crystallinity, improved surface morphology, and enhanced absorbance were shown after incorporation of $\mathrm{Rbl}$, as had been reported in previously published studies $[69,91]$.

Recently, post passivation of multi cation perovskite $\mathrm{Cs}_{0.10} \mathrm{FA}_{0.90} \mathrm{~Pb}\left(\mathrm{I}_{0.83} \mathrm{Br}_{0.17}\right)_{3}$ by rubidium butyrate $(\mathrm{RbBu})$ was reported to explain the role of $\mathrm{Rb}^{+}$and butyrate anion without affecting the perovskite crystallinity and surface morphology. After annealing of spin-coated $\mathrm{Cs}_{0.10} \mathrm{FA}_{0.90} \mathrm{~Pb}$ $\left(\mathrm{I}_{0.83} \mathrm{Br}_{0.17}\right)_{3}$ perovskite thin film, different concentrations ( 1 , $5,10,50$, and $100 \mathrm{mM}$ ) of RbBu sprinkled on it to study the charge carriers lifetime, diffusion length, resistance against 

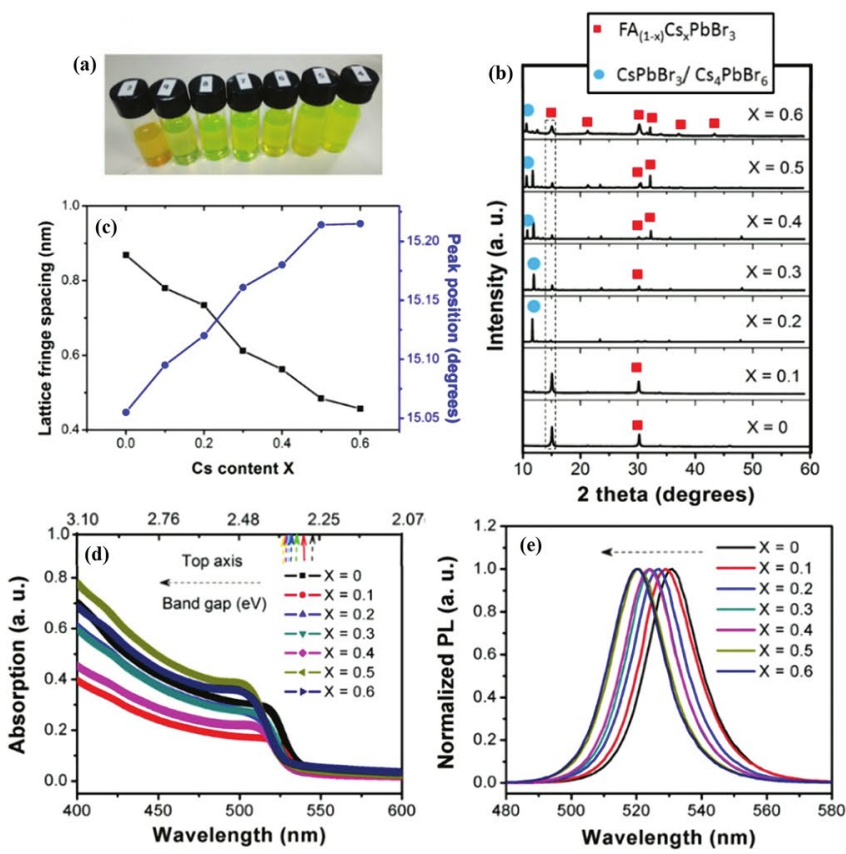

Fig. 2 a Photographs of different perovskite NCs in solution. $\mathbf{b}$ XRD patterns of $\mathrm{FA}_{(1-\mathrm{x})} \mathrm{Cs}_{\mathrm{x}} \mathrm{PbBr}_{3}(\mathrm{x}=0-0.6)$. c Lattice fringe and peak position $\left(\approx 15^{\circ}\right)$ as a function of Cs content, $x$, in $\mathrm{FA}_{(1-\mathrm{x})} \mathrm{Csx} \mathrm{PbBr}_{3}$. d Absorption spectra and e PL spectra of $\mathrm{FA}_{(1-x)} \mathrm{CsxPbBr}_{3}(\mathrm{x}=0-0.6)$.
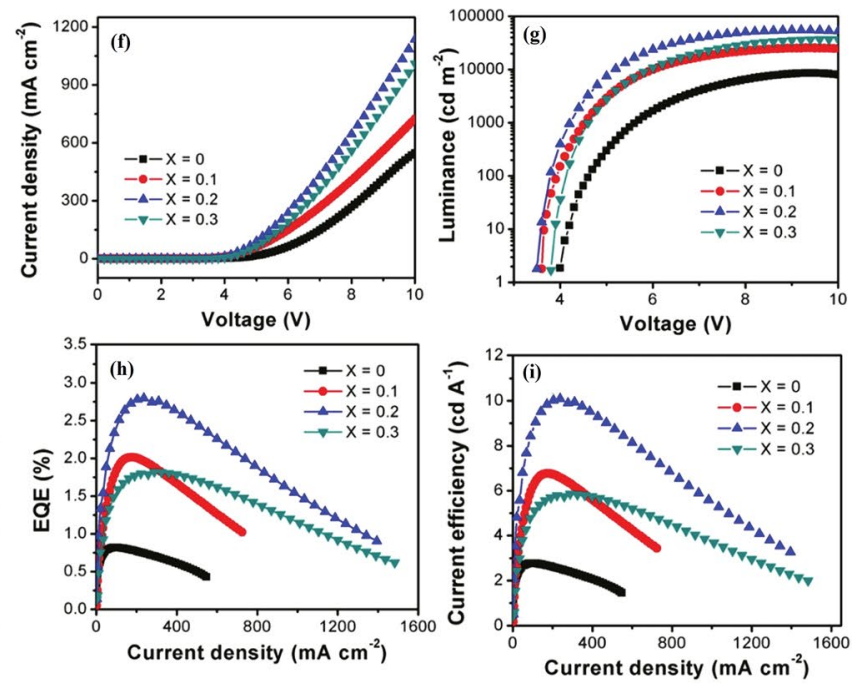

f J-V g luminance-voltage, h EQE-current density, and $\mathbf{i}$ current efficiency-current density characteristics of perovskite LEDs, based on $\mathrm{FA}_{(1-\mathrm{x})} \mathrm{Cs}_{\mathrm{x}} \mathrm{PbBr}_{3}(\mathrm{x}=0.0 .1,0.2$, and 0.3). Adapted with permission from ref. [80], copyright 2017, WILEY-VCH
Table 2 Summary of alkali metal-doped ions perovskite light-emitting diode

\begin{tabular}{|c|c|c|c|c|c|c|}
\hline Perovskite emitting layer & $\begin{array}{l}\text { Doped alkali } \\
\text { metal }\end{array}$ & $\mathrm{EL}[\mathrm{nm}]$ & $\begin{array}{l}\text { Luminance } \\
{\left[\mathrm{cd} / \mathrm{m}^{2}\right]}\end{array}$ & EQE \% & $\mathrm{CE}[\mathrm{cd} / \mathrm{A}]$ & [Ref] \\
\hline $\mathrm{MAPbBr}_{3}$ (Polycrystalline) & $\mathrm{Rb}$ & 527 & 7694 & - & 9.54 & [81] \\
\hline $\mathrm{FAPbBr}_{3}$ (Polycrystalline) & $\mathrm{Rb}$ & 532 & 66353 & 7.17 & 24.22 & [82] \\
\hline $\mathrm{CsFAPbBr}_{3}$ (QDs) & $\mathrm{Rb}$ & 502 & 750 & 3.60 & 8.50 & [83] \\
\hline $\mathrm{CsFAPbCl}_{1.25} \mathrm{Br}_{1.75}$ & & 466 & 39 & 0.61 & 0.45 & \\
\hline \multirow[t]{2}{*}{$\mathrm{CsPbBr}_{3}[\mathrm{NCs}]$} & $\mathrm{Rb}$ & 490 & 183 & 0.69 & - & [84] \\
\hline & & 464 & 63 & 0.11 & & \\
\hline $\mathrm{CsPbBr}_{3}[\mathrm{NCs}]$ & $\mathrm{K}$ & 522 & 5759 & 5.60 & - & {$[85]$} \\
\hline $\mathrm{CsPbl}_{3-\mathrm{x}} \mathrm{Br}_{\mathrm{x}}[\mathrm{NCs}]$ & $\mathrm{K}$ & 637 & 2671 & 3.55 & - & {$[86]$} \\
\hline $\mathrm{CsPb}(\mathrm{Br} / \mathrm{Cl})_{3}[\mathrm{NCs}]$ & $\mathrm{K}$ & 477 & 86.95 & 1.96 & & [87] \\
\hline $\mathrm{FAPbBr}_{3}[\mathrm{NCs}]$ & Cs & 525 & 55.005 & 2.80 & 10.09 & {$[80]$} \\
\hline $\mathrm{MAPbBr}_{3}[\mathrm{NCs}]$ & Cs & 523 & 24,500 & 1.30 & 4.10 & [88] \\
\hline
\end{tabular}

moisture, and photovoltaic performance. There is no obvious change in surface morphology from $\mathrm{RbBu}=0-10 \mathrm{mM}$ and grain sizes between 0.4 and $1.2 \mu \mathrm{m}$ were observed as shown in Fig. 4a. After that, rod-like crystals were noticed for the higher concentration of RbBu (50-100 mM) due to the presence of $\delta-\operatorname{RbPb}\left(\mathrm{Br}_{x} \mathrm{l}_{1-x}\right)_{3}$. To understand the effect of butyrate on the hydrophobicity of multi-cation perovskite, the maximum contact angle for RbBu-10 was recorded (Fig. 4b). As a general trend, the additives increases the charge carrier lifetime $\left(\tau_{\mathrm{s}}\right)$, and $\mathrm{RbBu}$ $(5 \mathrm{mM})$ showed a maximum lifetime of $\tau_{\mathrm{S}}=210 \mathrm{~ns}$ while drop-in charge-carrier mobility from $\mu=31.9 \mathrm{~cm}^{2} / \mathrm{Vs}$ to from $\mu=12.9 \mathrm{~cm}^{2} / \mathrm{Vs}$ exhibiting the role of different $\mathrm{RbBu}$ molar concentrations (Fig. 4c). Diffusion length $\left(L_{D}\right)$ measurements of the passivated films enhanced up to $5 \mu \mathrm{m}$ for $\mathrm{RbBu}=5 \mathrm{mM}$ and charge carrier diffusion length decreases to $2 \mu \mathrm{m}$ for higher or non-passivated perovskite films [92].

Another interesting aspect of rubidium ions has been studied to successfully solve the crystals phase instability and high-temperature thermal instability problems of $\mathrm{FAPbl}_{3}$ perovskite for high-performance photodetection. A large amount of $\mathrm{Rb}^{+}$ions (up to $30 \%$ ) was added to reduce 
(a)

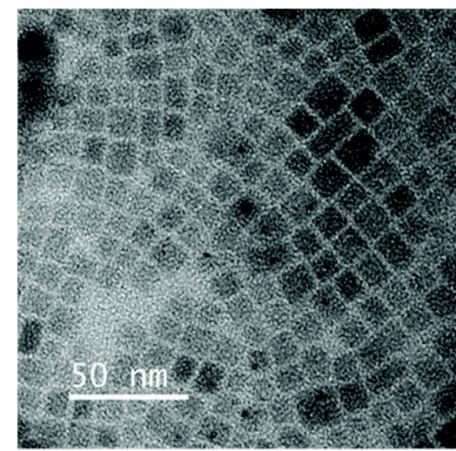

(d)

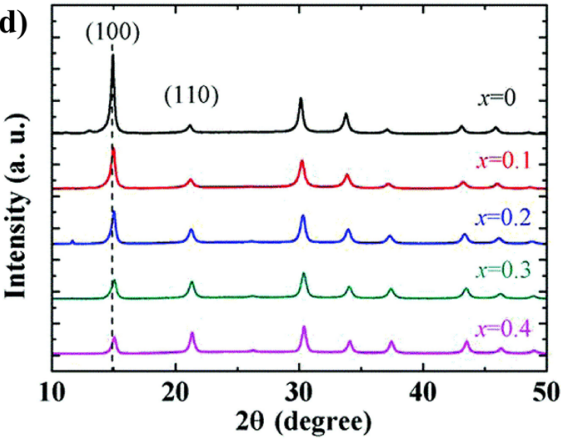

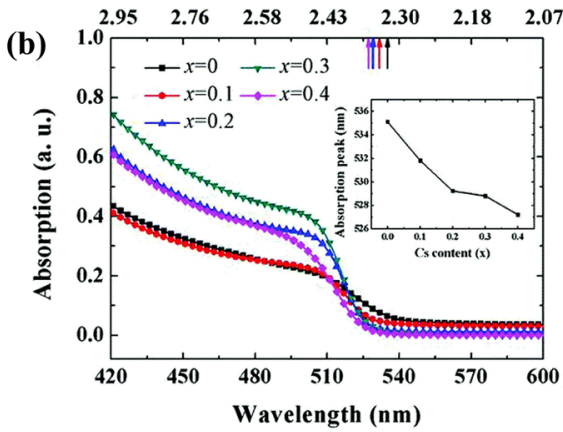

(e)

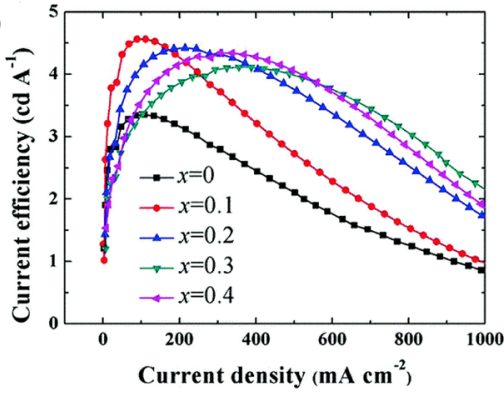

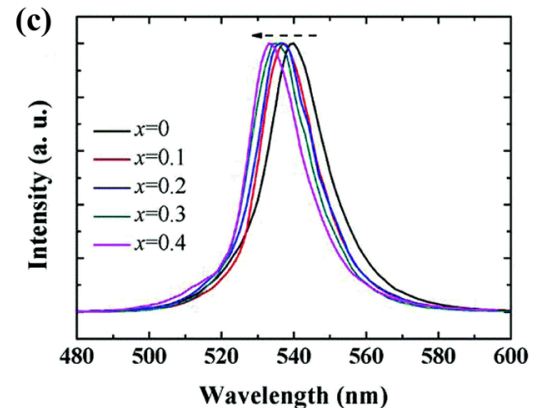

(f)

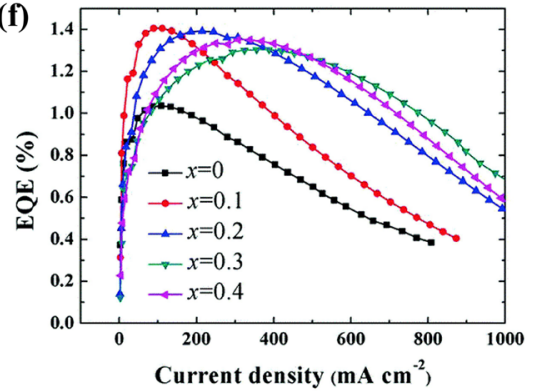

Fig. 3 a TEM image of the $\mathrm{MA}_{0.7} \mathrm{Cs}_{0.3} \mathrm{PbBr}_{3} \mathrm{NCs}$. b The absorption spectra, c PL spectra, d XRD patterns, e EQE versus current density and $\mathbf{f}$ luminance versus voltage, of $\mathrm{MA}_{1-\mathrm{x}} \mathrm{CsxPbBr}_{3}(\mathrm{x}=0-0.4)$.
Adapted with permission from ref. [88], copyright 2017, The Royal Society of Chemistry (a)

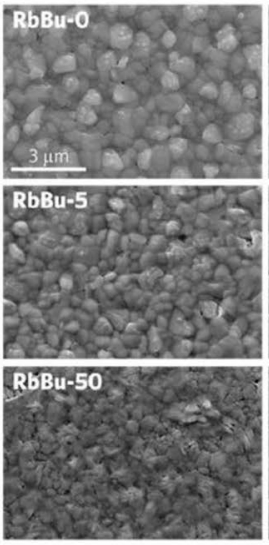

(c)
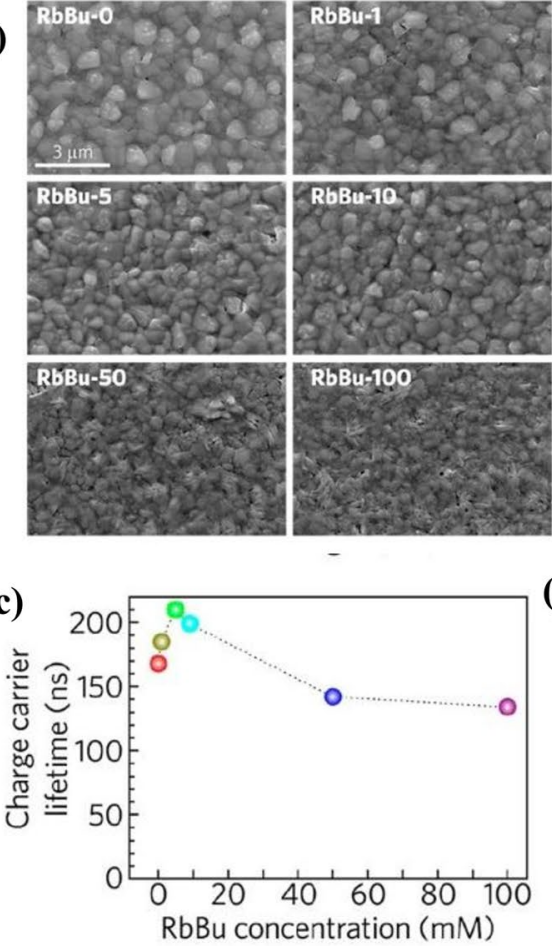

(b) RbBu-0

(d)

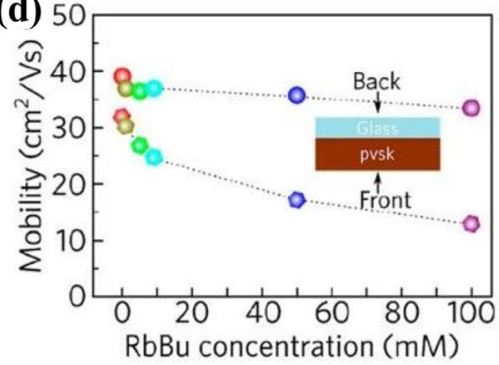

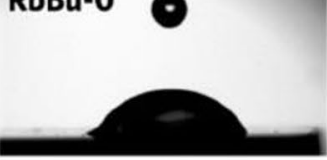

RbBu-10

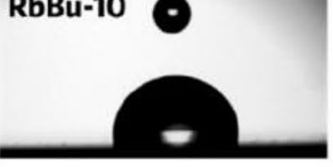

RbBu-1
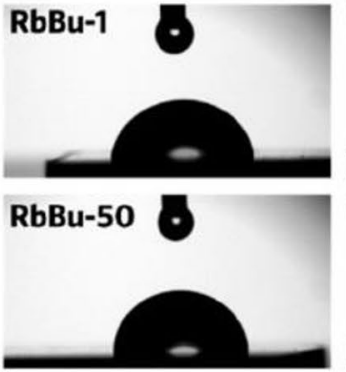

RbBu-5

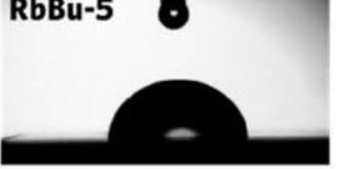

RbBu-100 -

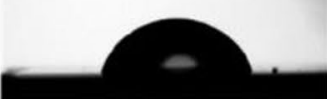

(e)

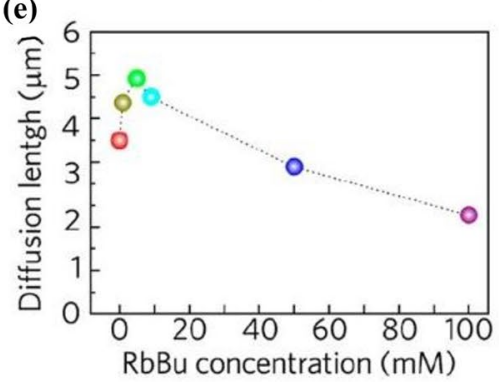

Fig. 4 a SEM images, b)= contact angle images and c charge-carrier lifetimes, d electron-hole sum mobilities from optical-pump terahertz-probe (OPTP) measurements, e charge-carrier diffusion lengths considering front face excitation as a function of the $\mathrm{RbBu}$ concentration. Adapted with permission from ref. [92], copyright 2020, American Chemical Society 
(a)

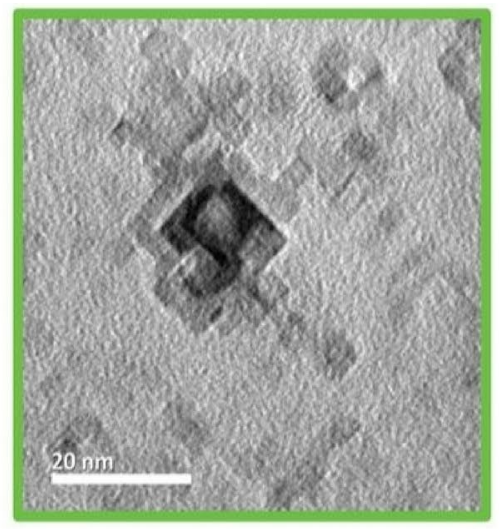

(b)

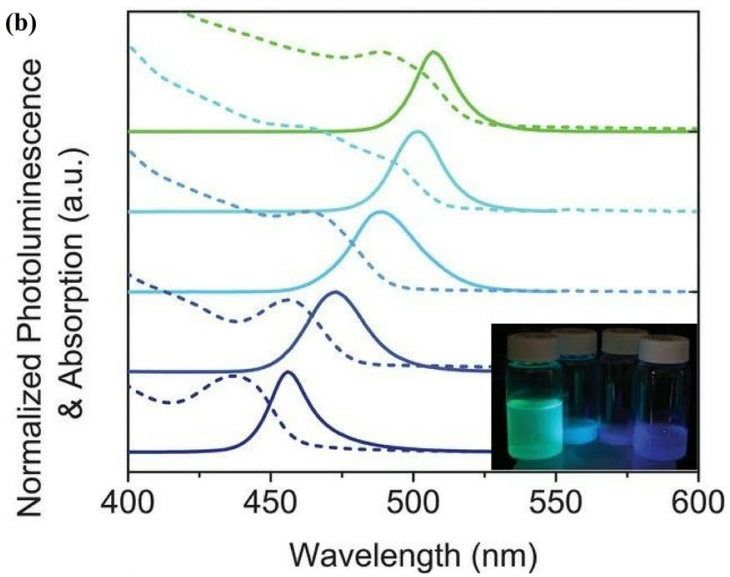

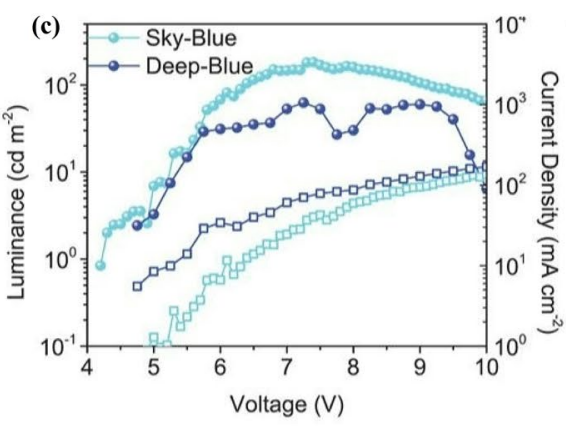

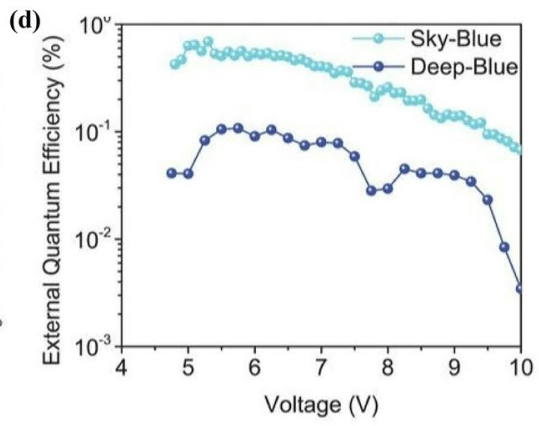

(e)

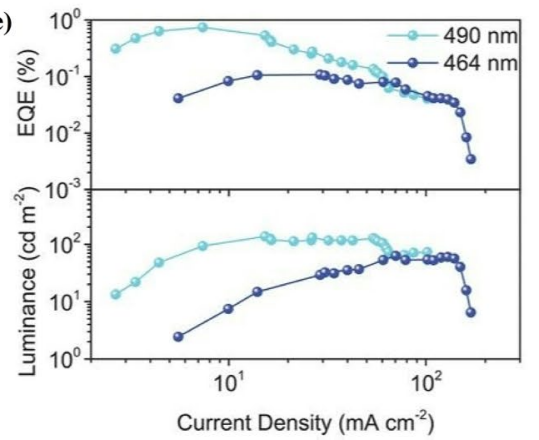

Fig. 5 a TEM images of synthesized $\mathrm{RbxCs}_{1-\mathrm{x}} \mathrm{PbBr}_{3}$ nanocubes $\mathbf{b}$ Photoluminescence (solid line) and absorption (dashed line) spectra of the synthesized solution. Inset is a picture of various solutions, illuminated by a UV-LED source $(\lambda=374 \mathrm{~nm})$ displaying the tunable emission. c Current density $(J)$ displayed by squares and luminance $(\mathrm{L})$ displayed by circles. $\mathbf{d}$ External quantum efficiency as a function of applied bias. e Devices that exhibited the largest luminance at their peak EQEs. Adapted with permission from ref. [84], copyright 2019, WILEY-VCH

Similarly, different nanostructures of $\mathrm{Rb}_{x} \mathrm{Cs}_{1-x} \mathrm{PbBr}_{3}$ (Fig. 5a) namely nanocubes and nanoplates with tunable emission (450-500 $\mathrm{nm}$ ) were reported to fabricate blue-emitting LEDs (Fig. 5b). The as-prepared nanoplates were of varying thicknesses and smaller in size due to the presence of $\mathrm{Rb}$ ions. The addition of $\mathrm{Rb}$ ions into the pure bromine phase could provide a path to increase the bandgap without introducing phase segregation at high voltage as it tends to distort the $\mathrm{PbX}_{6}$ octahedra and reduces the overall orbital overlap. As a result, high PLQY (>60\%), improved luminance, and EQE of $0.11-0.87 \%$ for deep-blue and sky-blue (Fig. $5 c-e$ ) LEDs were displayed [84].

Fanyaun et al. studied the interplay of $\mathrm{Rb}^{+}$ions to realize the severe challenges of $\mathrm{PL}$ and $\mathrm{EL}$ in multication blue-emitting perovskite quantum dots (QDs). It was noted that perovskite QDs exhibited cube-shaped and smaller size ( $5.17 \mathrm{~nm}$ vs $6.38 \mathrm{~nm}$ ) structures since $\mathrm{Rb}$ ions were incorporated into them. The addition of $\mathrm{Rb}^{+}$realized to enlarge the bandgap due to octahedral distortion and strong quantum confinement resulted 

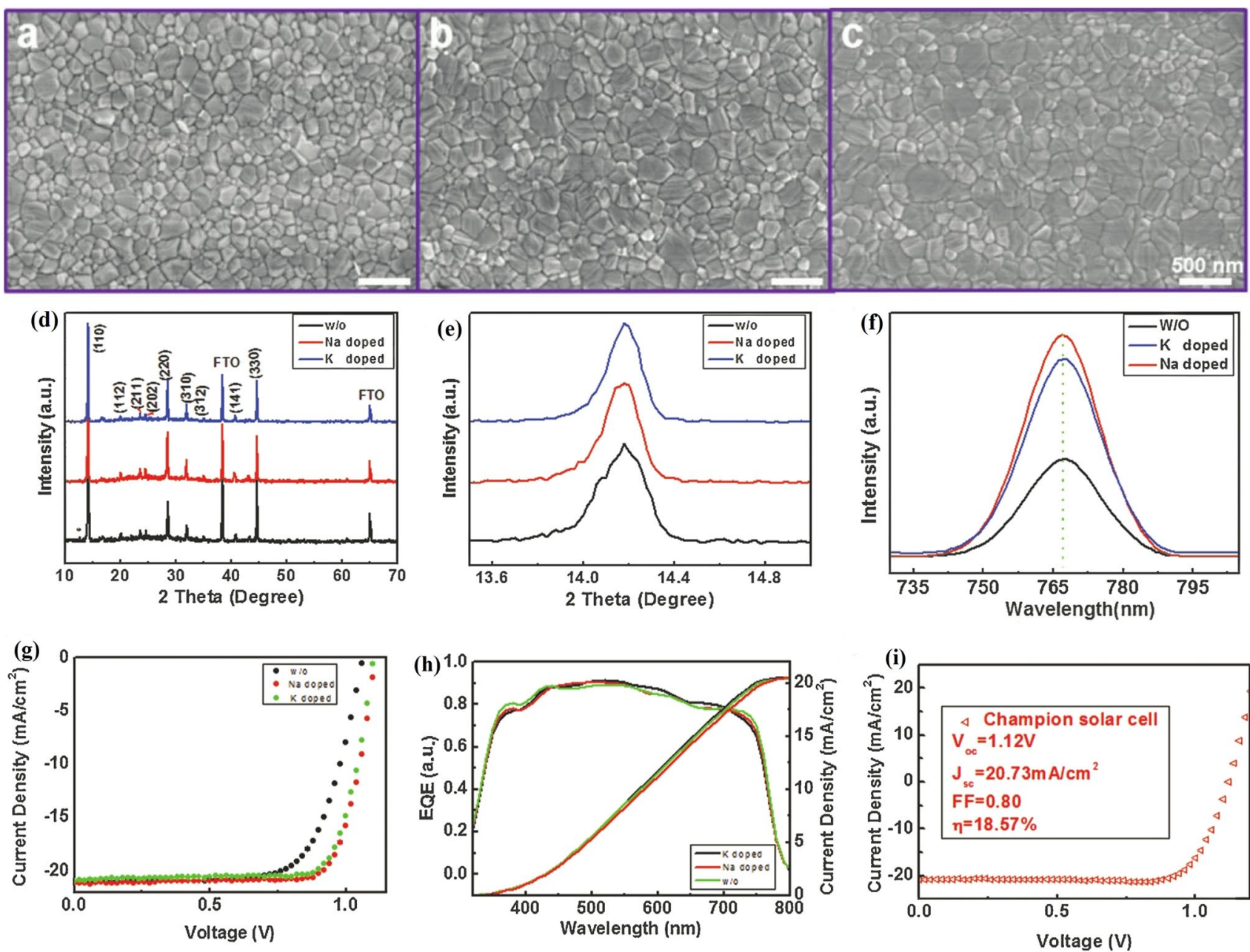

Fig. 6 SEM images of $\mathbf{a}$ without, or with $\mathbf{b} \mathrm{Nal} \mathbf{c} \mathrm{KI}$ doping $\mathbf{d}$ The $\mathrm{X}$ ray diffraction patterns e the enlarged comparison of (110) diffraction peak $\mathbf{f}$ the steady-state photoluminescence $(\mathrm{PL}) \mathbf{g}$ the current density-voltage characteristics and $\mathbf{h}$ external quantum efficiency (EQE) spectra with $\mathrm{Na}^{+}, \mathrm{K}^{+}$doped and the control sample without

in outstanding PLQY of $64.5 \%$ and $49.8 \%$ for greenish-blue $\left(\mathrm{Rb}_{0.33} \mathrm{Cs}_{0.67}\right)_{0.42} \mathrm{FA}_{0.58} \mathrm{PbBr}_{3}$ and deep-blue $\left(\mathrm{Rb}_{0.33} \mathrm{Cs}_{0.67}\right)_{0.42} \mathrm{FA}_{0.58} \mathrm{PbCl}_{1.25} \mathrm{Br}_{1.75}$ perovskite QDs [83].

\section{Incorporating other alkali metal ions $\left(\mathrm{K}^{+}\right.$, $\mathrm{Na}^{+}$, and $\mathrm{Li}^{+}$) for enhanced performance of HPM}

After studying beneficial aspects of rubidium, scientists were prompted to explore the other smaller alkali metal ions such as $\mathrm{K}^{+}, \mathrm{Na}^{+}$, and $\mathrm{Li}^{+}$. Previously published studies about polycrystalline perovskite thin films have been extensively reported about their high trap state density, enlarged grain boundaries, instability to heat, UV (ultraviolet), and humidity [96-98]. doping $\mathbf{i}$ The J-V curve of champion PSCs with $1.0 \mathrm{~mol} \% \mathrm{Na}^{+}$doping measured at the AM $1.5 \mathrm{G}$ solar spectra of $100 \mathrm{mWcm}^{-2}$ at a reverse scan. Adapted with permission from ref. [70], copyright 2017, WILEY-VCH

Wangen et al. investigated the role of alkali metal ions $\left(\mathrm{Na}^{+}, \mathrm{K}^{+}\right)$to make the $\mathrm{MAPbl}_{3}$ polycrystalline thin films with fewer trap states, reduced grain boundaries, and increased built-in potential leading to enhanced PCE. It was observed from morphological analysis (Fig. 6a-c), the addition of $\mathrm{Na}^{+}$and $\mathrm{K}^{+}$ions helps in high coverage and increases the grain size from $\approx 140 \mathrm{~nm}$ to $\approx 220 \mathrm{~nm}$ and $\approx 230 \mathrm{~nm}$, respectively. XRD analysis depicts (Fig. 6d-e) the typical tetragonal MAPbI3 phase of all samples and enlarged (110) peak with significantly narrow width showed that large grain sizes were obtained after addition of $\mathrm{Na}^{+}$and $\mathrm{K}^{+}$ions. To check the trap states of the perovskite absorber layer, steady-state PL spectra were recorded (Fig. 6f). An obvious increase in PL intensity was detected, that assigned to the reduced trap centres due to the coverage of grain boundaries by alkali metal ions. 
The J-V curves (Fig. $6 \mathrm{~g}-\mathrm{i}$ ) showed that both alkali $\mathrm{Na}^{+}$and $\mathrm{K}^{+}$have a positive effect on the overall performance of perovskite photovoltaic devices. There was a significant improvement in PCE from 15.56 to $18.16 \%$, an increase of $11.4 \%$ fill factor, and open circuit voltage improved from 1.06 to $1.10 \mathrm{~V}$ [70].

There is a large volume of published studies describing the impact of crystal native defects that can reduce the charge carrier lifetimes and stimulate the non-radiative recombination, hence reducing the device efficiency [99-102]. Lu et al. paved the way for the most common defect of iodine interstitials in the $\mathrm{MAPbl}_{3}$ perovskite by doping of $\mathrm{Li}, \mathrm{Na}, \mathrm{K}, \mathrm{Rb}$, and $\mathrm{Cs}$ atoms. It was found that the presence of alkali metal as dopant increases the formation energies up to fourfold for the halide interstitials defect and helps in maintaining the high concentration of charge carriers. In addition, charge carrier recombination lifetime follow the trend, pristine $<\mathrm{Li}<\mathrm{Na}<\mathrm{K}<\mathrm{Rb}<\mathrm{Cs}$ [103]. A brief list of radiative lifetime analysis of alkali doped HPM is given in Table 3.

Besides studying the influence of potassium on polycrystalline HPM, a considerable amount of literature has also been published on nanocrystalline HPM. It has been well reported as the passivating agent to form potassium halide layer to overcome halide segregation in mixedhalide perovskite thin films. Moreover, modification of grain boundaries and suppression of ions migration are the potential benefits of using potassium in HPM [64].

Halide segregation is a major problem in mixed HPM which results in poor electro luminance (EL) stability in LEDs. To overcome this problem, potassium bromide surface coated all inorganic $\mathrm{CsPbl}_{3-\mathrm{x}} \mathrm{Br}_{\mathrm{x}} \mathrm{NCs}$ emitting at

Table 3 Radiative lifetime analysis for the alkali doped halide perovskite materials

\begin{tabular}{|c|c|c|c|c|}
\hline Perovskite & $\begin{array}{l}\text { Doped } \\
\text { alkali ele- } \\
\text { ment }\end{array}$ & $\begin{array}{l}\text { Morphology of } \\
\text { perovskite film }\end{array}$ & $\begin{array}{l}\text { Radiative } \\
\text { lifetime } \\
\text { (ns) }\end{array}$ & Ref \\
\hline $\mathrm{CsPbl}_{3-\mathrm{x}} \mathrm{Br}_{\mathrm{x}}$ & $\mathrm{K}$ & Nanocrystalline & 8.73 & [86] \\
\hline $\mathrm{CsPbCl}_{3}$ & $\mathrm{~K}$ & Nanocrystalline & 2.10 & [104] \\
\hline $\mathrm{CsPbBr}_{3}$ & $\mathrm{~K}$ & Nanocrystalline & 2.21 & [85] \\
\hline $\begin{array}{c}\mathrm{FA}_{0.85} \mathrm{MA}_{0.15} \mathrm{~Pb} \\
(10.85 \mathrm{Br} 0.15) 3\end{array}$ & $\mathrm{~K}$ & Polycrystalline & 32.7 & [71] \\
\hline $\mathrm{CsPb}(\mathrm{Br} / \mathrm{Cl})_{3}$ & $\mathrm{~K}$ & Nanocrystalline & 4.57 & [87] \\
\hline $\mathrm{FAPbBr}_{3}$ & $\mathrm{Rb}$ & Polycrystalline & 2.77 & [82] \\
\hline $\mathrm{CsPbBr}_{3}$ & $\mathrm{Rb}$ & Nanocrystalline & 4.7 & [83] \\
\hline $\mathrm{CsFAPbBr}_{3}$ & & & 3.2 & \\
\hline $\mathrm{CsFAPbCl}_{3-\mathrm{x}} \mathrm{Br}_{\mathrm{x}}$ & & & 3.5 & \\
\hline $\mathrm{CsPbBr}_{3}$ & $\mathrm{Rb}$ & Nanocrystalline & 5.47 & [84] \\
\hline $\mathrm{MAFAPbBr}_{3}$ & $\mathrm{Rb}$ & Polycrystalline & 4.68 & [63] \\
\hline $\mathrm{FAPbBr}_{3}$ & Cs & Nanocrystalline & 4.80 & {$[80]$} \\
\hline
\end{tabular}

$640 \mathrm{~nm}$ were synthesized via hot-injection method. The resulting potassium passivated high-quality NCs showed above $90 \%$ PLQY and good dispersion stability for weeks. As a result, pure red-emitting LEDs at $637 \mathrm{~nm}$ exhibited a highly stable brightness of $2671 \mathrm{cdm}^{-2}$ and EQE of $3.55 \%$ [86].

Several reports [105-108] have shown that blue perovskite LEDs still lag behind the red and green ones due to difficulties in synthesizing stable materials, maintaining high quantum efficiency, and halide segregation to get required emission parameters. The small amount of impurity ion doping has been considered as an effective strategy to improve the optical properties of nanocrystalline HPM. Several studies have been published on doping of a variety of ions including lanthanides [109] and manganese [110] with great success. However, the introduction of new emission due to additional ions cause the impurity in blue light. Smaller size alkali metal ions have the advantage to enhance the efficiency of blue-emitting devices without disturbing the original emission spectra. Given the low performance of $\mathrm{CsPCl}_{3}$ QDs, doping of potassium ions was introduced for controlling the emission properties of blue-violet light and a blue shift in absorption edge was observed. Only a small amount of potassium ions enhanced the PLQY of perovskite QDs at $408 \mathrm{~nm}$ from 3.2 to $10.3 \%$ [104].

To further study the role of potassium incorporation into the $\mathrm{CsPb}(\mathrm{Br} / \mathrm{Cl})_{3} \mathrm{NCs}$, Fei et al. demonstrated the use of $\mathrm{K}^{+}$ions as metal-ligand to improve the nonradiative recombination and PLQY. It is clear from the XRD peaks (Fig. 7a) that all samples showed the characteristic peaks of typical cubic crystal planes of $\mathrm{CsPb}(\mathrm{Br} / \mathrm{Cl})_{3}$, with no additional diffraction peak confirming the presence of $\mathrm{K}^{+}$ions as capping agent outside the crystal surface. The transmission electron microscopy (TEM) images (Fig. 7b-c) exhibit the lattice plane of (200) and (211), which further confirm that the addition of $\mathrm{K}^{+}$ions does not affect the crystal structure. The NCs exhibit a slight increase in size with the addition of $\mathrm{K}^{+}$as shown in size distribution histograms (Fig. $7 \mathrm{~b}-\mathrm{C}$ ), where the average size for the untreated and $\mathrm{K}^{+}$treated is $9.94 \mathrm{~nm}$ and $10.92 \mathrm{~nm}$ respectively. It was demonstrated that alkali metal doping methods can accelerate the speed of reaction, leading to an increase of the NCs size.

Moreover, a schematic presentation (Fig. $7 \mathrm{~d}$ ) of $\mathrm{K}^{+}$ions bonding with halides verified the reduced amount of insulating ligands around the NCs. In terms of device performance (Fig. 7e-f, Table 2), the champion blue perovskite LED with $4.0 \%$ of $\mathrm{K}^{+}$ions showed the highest EQE of $1.96 \%$ and luminance of $86.95 \mathrm{~cd} \mathrm{~m}^{-2}$ [87].

In contrast to this study, Minh et al. demonstrated that potassium doping of $\mathrm{NCs}$ can enhance the coverage of capping ligands around $\mathrm{CsPbBr}_{3}$ nanocrystal confirmed 

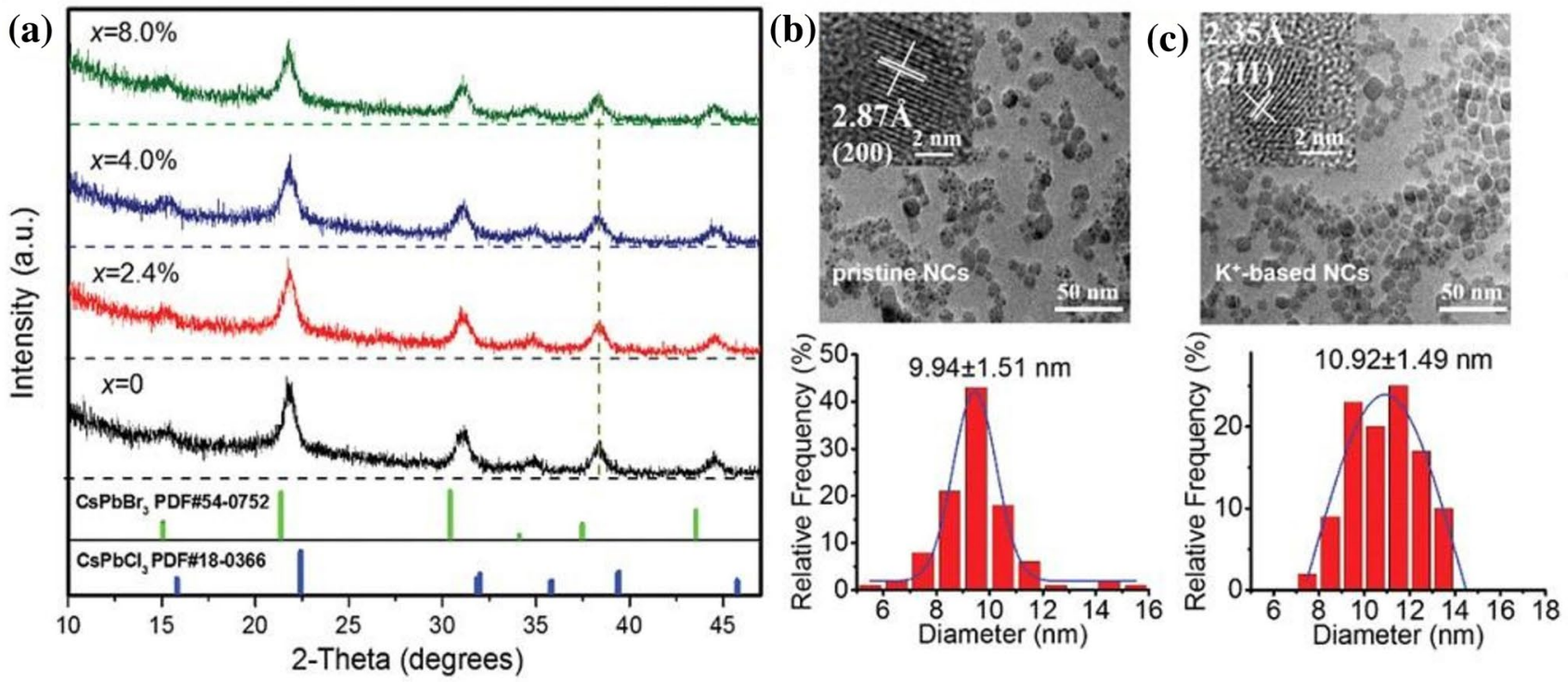

(d)

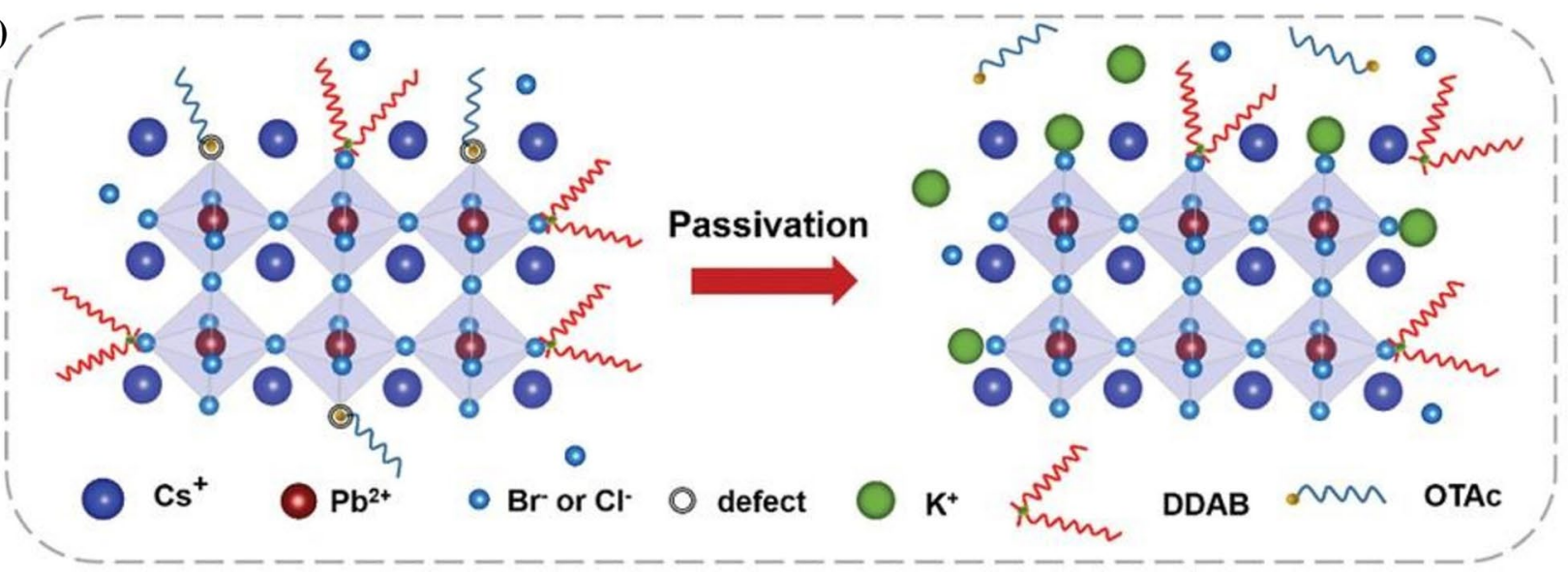

(e)

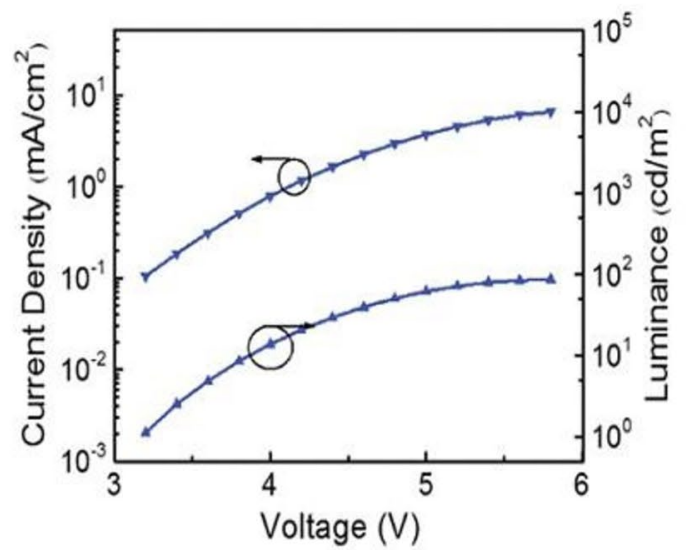

(f)

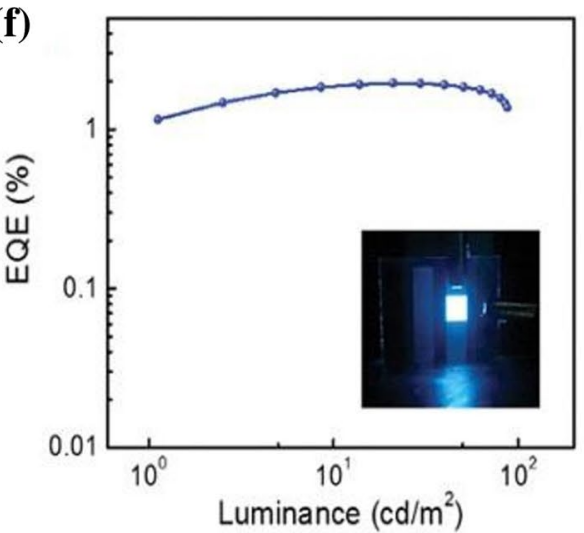

Fig. 7 a XRD patterns of perovskite films with different $x$ values and standard XRD patterns of $\mathrm{CsPbBr}_{3}$ and $\mathrm{CsPbCl}_{3} \cdot \mathbf{b}$ and $\mathbf{c}$ TEM images of pristine and $\mathrm{K}^{+}$based $\left(4.0 \%\right.$ in terms of nominal $\mathrm{K}^{+}$ratio) $\mathrm{NCs}$ and size distribution analysis; the insets show the corresponding high- resolution TEM images. $\mathbf{d}$ Schematic illustration of potassium passivation. e Current density-voltage-luminance curves and $f \mathrm{EQE}-$ luminance curve for LED device based on $x=4.0 \%$. Adapted with permission from ref [87], copyright 2020, WILEY-VCH 
by $\mathrm{N}-\mathrm{H}$ stretching at $3356 \mathrm{~cm}^{-1}$. The reason for increased stretching is due to better oleylamine coverage which could be ascribed to the formation of the bromide-rich surface due to potassium ions. Furthermore, Fourier transforms infrared (FTIR) peaks of $2.5 \%$ potassium doped sample showed nearly double intensity as compared to the sample without doping. Also, reduction in trap states and reduced surface energy of NCs were believed due to the more insulating ligands attached to the NCs surface [85].

\section{Conclusion and outlook}

In this review, we summarized comprehensive progress on doping of alkali metal ions $\left(\mathrm{Li}^{+}, \mathrm{Na}^{+}, \mathrm{K}^{+}, \mathrm{Rb}^{+}, \mathrm{Cs}^{+}\right)$in terms of their ability to markedly influence the electrical, optical, and doping induced charge carrier dynamics in halide perovskite materials. Alkali metals have been successfully doped in polycrystalline halide perovskites, giving rise to structural stability, reduced defect states, enlarged grain boundaries, and improved film morphology. Moreover, alkali metal-doped NCs have shown reduced crystal native defects, improved thermal and moisture stability, prolonged charge carrier lifetime, and high PLQY.

Looking forward, to fully exploring the potential benefits of alkali metals in perovskites, considerably more research work will need to be done to determine the true position of alkali metals ions, the influence of doping on crystal orientation, and the principle behind the improved optoelectronic properties. Also, there is a wide research gap in co-doping the high-band gap perovskite to enhance stability and to cover a wide luminance range. Thus, we expect that advanced characterization techniques such as in-situ transmission electron microscopy should be implemented to study the influence of the incorporation of alkali metal ions. At present, alkali metaldoped perovskites are mostly reported for solar cells and LEDs construction. Keeping in mind the unique properties of alkali metals in perovskites, doped perovskites should consider in other applications such as photodetectors, X-ray detectors, and single-photon sources.

Acknowledgements We acknowledge financial support from Higher Education Commission Pakistan (HRDI UESTPs/UET's-PhaseI/6016/2018) and Queen Mary, University of London.

\section{Declarations}

Conflict of interest There are no conflicts of interest to declare.

Open Access This article is licensed under a Creative Commons Attribution 4.0 International License, which permits use, sharing, adaptation, distribution and reproduction in any medium or format, as long as you give appropriate credit to the original author(s) and the source, provide a link to the Creative Commons licence, and indicate if changes were made. The images or other third party material in this article are included in the article's Creative Commons licence, unless indicated otherwise in a credit line to the material. If material is not included in the article's Creative Commons licence and your intended use is not permitted by statutory regulation or exceeds the permitted use, you will need to obtain permission directly from the copyright holder. To view a copy of this licence, visit http://creativecommons. org/licenses/by/4.0/.

\section{References}

1. Nguyen V, Katsuki H, Sasaki F, Yanagi H (2018) Single-crystal perovskite $\mathrm{CH}_{3} \mathrm{NH}_{3} \mathrm{PbBr}_{3}$ prepared by cast-capping method for light-emitting diodes. JJAP 10:2-5. https://doi.org/10.7567/ SSDM.2017.B-1-03

2. Tan Z, Moghaddam R, Lai M et al (2014) (2014) Bright lightemitting diodes based on organometal halide perovskite. Nat Nanotechnol 9(9):687-692. https://doi.org/10.1038/nnano. 2014.149

3. Shen Y, Cheng L, LiY, Chen J, Lee S et al (2019) High-efficiency perovskite light-emitting diodes with synergetic outcoupling enhancement. Adv Mater. https://doi.org/10.1002/adma.201901517

4. Rudd PN, Huang J (2019) Metal ions in halide perovskite materials and devices. Trends Chem 1(4):394-409. https://doi.org/10. 1016/j.trechm.2019.04.010

5. Fu Y, Zhu H, Chen J, Hautzinger MP, Zhu XY, Jin S (2019) Metal halide perovskite nanostructures for optoelectronic applications and the study of physical properties. Nat Rev Mater 4(3):169-188. https://doi.org/10.1038/s41578-019-0080-9

6. Lu CH, Biesold-Mcgee GV, Liu Y, Kang Z, Lin Z (2020) Doping and ion substitution in colloidal metal halide perovskite nanocrystals. Chem Soc Rev 49(14):4953-5007. https://doi.org/10.1039/ c9cs00790c

7. Zhang Q, Yin Y, Yin Y (2018) All-Inorganic metal halide perovskite nanocrystals: opportunities and challenges. ACS Cent Sci 4:668-679. https://doi.org/10.1021/acscentsci.8b00201

8. Liu M, Ali-Loytty H, Hiltunen A et al (2021) Manganese doping promotes the synthesis of bismuth-based perovskite nanocrystals while tuning their band structures. Small. https://doi.org/ 10.1002/smll.202100101

9. Liu M, Pasanen H, Ali-Loyetty $\mathrm{H}$ et al (2020) B-site co-alloying with germanium improves the efficiency and stability of allinorganic tin-based perovskite nanocrystal solar cells. Angew Chemie. https://doi.org/10.1002/ange.202008724

10. Wali Q, Iftikhar FJ, Khan ME, Ullah A, Iqbal Y, Jose R (2020) Advances in stability of perovskite solar cells. Org Electron. https://doi.org/10.1016/j.orgel.2019.105590

11. Grancini G, Nazeeruddin MK (2019) Dimensional tailoring of hybrid perovskites for photovoltaics. Nat Rev Mater. https:// doi.org/10.1038/s41578-018-0065-0

12. Vidyasagar CC, Muñoz Flores BM, Jiménez Pérez VM (2008) Recent advances in synthesis and properties of hybrid halide perovskites for photovoltaics. Nano-Micro Lett. https://doi.org/ 10.1007/s40820-018-0221-5

13. Zhou D, Zhou T, Tian Y, Zhu X, Tu Y (2018) Perovskite-based solar cells: materials, methods, and future perspectives. J Nanomater. https://doi.org/10.1155/2018/8148072

14. Zhou Y, Chen J, Bakr OM, Sun HT (2018) Metal-doped lead halide perovskites: synthesis, properties, and optoelectronic applications. Chem Mater. https://doi.org/10.1021/acs.chemm ater.8b02989

15. Abdelhady AL, Saidaminov M, Murali B et al (2016) Heterovalent dopant incorporation for bandgap and type engineering of perovskite crystals. J Phys Chem Lett. https://doi.org/10. 1021/acs.jpclett.5b02681 
16. Sherkar TS, Momblona C, Gil-Escrig L et al (2017) Recombination in perovskite solar cells: significance of grain boundaries, interface traps, and defect ions. ACS Energy Lett. https://doi. org/10.1021/acsenergylett.7b00236

17. Zhao P, Kim BJ, Jung HS (2018) Passivation in perovskite solar cells: a review. Mater Today Energy. https://doi.org/10.1016/j. mtener.2018.01.004

18. Wang F, Bai S, Tress W, Hagfeldt A, Gao F (2018) Defects engineering for high-performance perovskite solar cells. npj Flex Electron. https://doi.org/10.1038/s41528-018-0035-z

19. Wang K, Subhani W, Wang Y et al (2019) Metal cations in efficient perovskite solar cells: progress and perspective. Adv Mater. https://doi.org/10.1002/adma.201902037

20. Das Adhikari S, Dutta SK, Dutta A, Guria AK, Pradhan N (2017) Chemically tailoring the dopant emission in manganesedoped $\mathrm{CsPbCl}_{3}$ perovskite nanocrystals. Angew Chemie: Int Ed. https://doi.org/10.1002/anie.201703863

21. Mir WJ, Jagadeeswararao M, Das S, Nag A (2017) Colloidal Mn-doped cesium lead halide perovskite nanoplatelets. ACS Energy Lett. https://doi.org/10.1021/acsenergylett.6b00741

22. Meinardi F, Akkerman Q, Bruni F et al (2017) Doped halide perovskite nanocrystals for reabsorption-free luminescent solar concentrators. ACS Energy Lett. https://doi.org/10.1021/acsen ergylett.7b00701

23. Zhang X, Li L, Sun Z, Luo J (2019) Rational chemical doping of metal halide perovskites. Chem Soc Rev 48(2):517-539. https:// doi.org/10.1039/c8cs00563j

24. Yang Z, Wei M, Voznyy $O$ et al (2020) Anchored ligands facilitate efficient B-site doping in metal halide perovskites. J Am Chem Soc. https://doi.org/10.1021/jacs.9b02565

25. Cai Y, Xie L, Zhang Z et al (2019) Tuning the A-site cation and $\mathrm{X}$-site anion composition of $\mathrm{CH}_{3} \mathrm{NH}_{3} \mathrm{Pbl}_{3}$ perovskite material for efficient planar perovskite solar cells. Electrochim Acta. https:// doi.org/10.1016/j.electacta.2018.10.034

26. Luo B, Lei F, Xu K et al (2019) B-Site doped lead halide perovskites: Synthesis, band engineering, photophysics, and light emission applications. J Mater Chem C. https://doi.org/ 10.1039/c8tc05741a

27. Swarnkar A, Mir WJ, Nag A (2018) Can B-site doping or alloying improve thermal- and phase-stability of all-inorganic $\mathrm{CsPbX}_{3}(\mathrm{X}$ $=\mathrm{Cl}, \mathrm{Br}, \mathrm{I})$ perovskites? ACS Energy Lett. https://doi.org/10. 1021/acsenergylett.7b01197

28. Xu L, Yuan S, Zeng H, Song J (2019) A comprehensive review of doping in perovskite nanocrystals/quantum dots: evolution of structure, electronics, optics, and light-emitting diodes. Mater Today Nano. https://doi.org/10.1016/j.mtnano.2019.100036

29. Kim J, Ho-Baillie A, Huang S (2019) Review of novel passivation techniques for efficient and stable perovskite solar cells. Solar RRL. https://doi.org/10.1002/solr.201800302

30. Yang CH, Kan D, Takeuchi I, Nagarajan V, Seidel J (2012) Doping $\mathrm{BiFeO}_{3}$ : approaches and enhanced functionality. Phys Chem Chem Phys. https://doi.org/10.1039/c2cp43082g

31. Bartel CJ, Sutton C, Goldsmith B et al (2018) New tolerance factor to predict the stability of perovskite oxides and halides. arXiv. https://doi.org/10.1126/sciadv.aav0693

32. Sato T, Takagi S, Deledda S, Hauback BC, Orimo SI (2016) Extending the applicability of the goldschmidt tolerance factor to arbitrary ionic compounds. Sci Rep 6:1-10. https://doi. org/10.1038/srep23592

33. Li C, Lu X, Ding W, Feng L, Gao Y, Guo Z (2008) Formability of $\mathrm{ABX}_{3}(\mathrm{X}=\mathrm{F}, \mathrm{Cl}, \mathrm{Br}, \mathrm{I})$ halide perovskites. Acta Crystallogr Sect $\mathrm{B}$ Struct Sci. https://doi.org/10.1107/S0108768108032734

34. Kieslich G, Sun S, Cheetham AK (2015) An extended tolerance factor approach for organic-inorganic perovskites. Chem Sci. https://doi.org/10.1039/c5sc00961h
35. Fu Y, Hautainger M, Luo Z et al (2019) Incorporating large a cations into lead iodide perovskite cages: relaxed goldschmidt tolerance factor and impact on exciton-phonon interaction. ACS Cent Sci. https://doi.org/10.1021/acscentsci.9b00367

36. Jiang J, Xu J, Walter $\mathrm{H}$ et al (2019) The doping of alkali metal for halide perovskites. ES Mater Manuf. https://doi.org/10.30919/ esmm5f705

37. Liu T, Zong Y, Zhou Y et al (2017) High-performance formamidinium-based perovskite solar cells via microstructure-mediated $\delta$-to-a phase transformation. Chem Mater. https://doi.org/ 10.1021/acs.chemmater.7b00523

38. Syzgantseva OA, Saliba M, Grätzel M, Rothlisberger U (2017) Stabilization of the perovskite phase of formamidinium lead triiodide by methylammonium, Cs, and/or Rb doping. J Phys Chem Lett 8(6):1191-1196. https://doi.org/10.1021/acs.jpclett. $6 \mathrm{~b} 03014$

39. Hoefler SF, Trimmel G, Rath T (2017) Progress on lead-free metal halide perovskites for photovoltaic applications: a review. Monatshefte Fur Chemie. https://doi.org/10.1007/ s00706-017-1933-9

40. Zhang C, Wang Y, Lin X et al (2020) Effects of A site doping on the crystallization of perovskite films. J Mater Chem A. https:// doi.org/10.1039/d0ta08656h

41. Kim S, Eom T, Ha YS, Hong KH, Kim H (2020) Thermodynamics of multicomponent perovskites: a guide to highly efficient and stable solar cell materials. Chem Mater. https://doi.org/10. 1021/acs.chemmater.0c00893

42. Hartono NTP, Sun S, Gelvez-Rueda M et al (2019) The effect of structural dimensionality on carrier mobility in lead-halide perovskites. J Mater Chem A. https://doi.org/10.1039/c9ta05241k

43. Eperon GE, Stone K, Mundt L et al (2020) The role of dimethylammonium in bandgap modulation for stable halide perovskites. ACS Energy Lett. https://doi.org/10.1021/acsenergylett. 0c00872

44. Ginting RT, Jung ES, Jeon MK, Jin WY, Song M, Kang JW (2016) Low-temperature operation of perovskite solar cells: with efficiency improvement and hysteresis-less. Nano Energy. https:// doi.org/10.1016/j.nanoen.2016.08.016

45. Targhi FF, Jalili YS, Kanjouri F (2018) $\mathrm{MAPbl}_{3}$ and $\mathrm{FAPbl}_{3}$ perovskites as solar cells: case study on structural, electrical and optical properties. Results Phys. https://doi.org/10.1016/j.rinp. 2018.07.007

46. Lee JW, Kim DH, Kim HS, Seo SW, Cho SM, Park NG (2015) Formamidinium and cesium hybridization for photo- and moisturestable perovskite solar cell. Adv Energy Mater. https://doi.org/ 10.1002/aenm.201501310

47. Li Z, Yang M, Park JS, Wei SH, Berry JJ, Zhu K (2016) Stabilizing perovskite structures by tuning tolerance factor: formation of formamidinium and cesium lead iodide solid-state alloys. Chem Mater. https://doi.org/10.1021/acs.chemmater.5b04107

48. Saliba M, Matsui T, Seo J et al (2016) Cesium-containing triple cation perovskite solar cells: Improved stability, reproducibility and high efficiency. Energy Environ Sci. https://doi.org/10. 1039/c5ee03874j

49. Xie $L$, Song $P$, Shen $L$ et al (2020) Revealing the compositional effect on the intrinsic long-term stability of perovskite solar cells. J Mater Chem A. https://doi.org/10.1039/d0ta01668c

50. Qin $\mathrm{M}$, Xue $\mathrm{H}$, Zhang $\mathrm{H}$ et al (2020) Precise control of perovskite crystallization kinetics via sequential A-site doping. Adv Mater. https://doi.org/10.1002/adma.202004630

51. Prochowicz D, Runjhun R, Tavakoli M et al (2019) Engineering of perovskite materials based on formamidinium and cesium hybridization for high-efficiency solar cells. Chem Mater. https://doi.org/10.1021/acs.chemmater.8b04871 
52. Amat A, Mosconi E, Ronca E et al (2014) Cation-induced bandgap tuning in organohalide perovskites: interplay of spin-orbit coupling and octahedra tilting. Nano Lett. https://doi.org/10. 1021/nl5012992

53. Murugadoss $G$, Thangamuthu R, Vijayaraghavan $S$, Kanda $H$, Ito $S$ (2017) Caesium: methyl ammonium mixed-cation lead iodide perovskite crystals - analysis and application for perovskite solar cells. Electrochim Acta. https://doi.org/10.1016/j. electacta.2017.10.092

54. Fan Y, Qin H, Ye W, Liu M, Huang F, Zhong D (2018) Improving the stability of methylammonium lead iodide perovskite solar cells by cesium doping. Thin Solid Films. https://doi.org/10. 1016/j.tsf.2018.10.001

55. Ye F, Yang W, Luo D, Zhu R, Gong Q (2017) Applications of cesium in the perovskite solar cells. J Semicond. https://doi. org/10.1088/1674-4926/38/1/011003

56. Choi H, Jeong J, Kim H et al (2014) Cesium-doped methylammonium lead iodide perovskite light absorber for hybrid solar cells. Nano Energy. https://doi.org/10.1016/j.nanoen.2014.04.017

57. Wu G, Sun R, Hu L et al (2020) Synergistic benefits of cesiumdoped aqueous precursor in air-processed inverted perovskite solar cells. Sol RRL. https://doi.org/10.1002/solr.201900406

58. Jiang $Q$, Zhao $Y$, Zhang $X$ et al (2019) Surface passivation of perovskite film for efficient solar cells. Nat Photonics. https:// doi.org/10.1038/s41566-019-0398-2

59. Zhang Y, Kim SG, Lee D, Shin H, Park NG (2019) Bifacial stamping for high efficiency perovskite solar cells. Energy Environ Sci. https://doi.org/10.1039/c8ee02730g

60. Yuan S, Cai Y, Yang S et al (2019) Simultaneous cesium and acetate coalloying improves efficiency and stability of $\mathrm{FA}_{0.85} \mathrm{MA}_{0.15} \mathrm{Pbl}_{3}$ perovskite solar cell with an efficiency of 21.95. Sol RRL. https://doi.org/10.1002/solr.201900220

61. Gao B, Meng J (2020) RbCs(MAFA)Pbl3 perovskite solar cell with $22.81 \%$ efficiency using the precise ions cascade regulation. Appl Surf Sci. https://doi.org/10.1016/j.apsusc.2020.147240

62. Saliba M, Matsui T, Domanski K et al (2016) Incorporation of rubidium cations into perovskite solar cells improves photovoltaic performance. Science (80-). https://doi.org/10.1126/scien ce.aah5557

63. Duong T, Mulmudi H, Shen $\mathrm{H}$ et al (2016) Structural engineering using rubidium iodide as a dopant under excess lead iodide conditions for high efficiency and stable perovskites. Nano Energy. https://doi.org/10.1016/j.nanoen.2016.10.027

64. Abdi-Jalebi M, Andaji Z, Coca S et al (2018) Maximizing and stabilizing luminescence from halide perovskites with potassium passivation. Nature. https://doi.org/10.1038/natur e25989

65. Kuai L, Wang Y, Zhang Z et al (2019) Passivating crystal boundaries with potassium-rich phase in organic halide perovskite. Sol RRL. https://doi.org/10.1002/solr.201900053

66. Prochowicz D, Tavakoli M, Kalam A et al (2019) Influence of A-site cations on the open-circuit voltage of efficient perovskite solar cells: a case of rubidium and guanidinium additives. J Mater Chem A. https://doi.org/10.1039/c9ta00272c

67. Guo Y, Zhao F, Tao J et al (2019) Efficient and hole-transportinglayer-free $\mathrm{CsPbl}_{2} \mathrm{Br}$ planar heterojunction perovskite solar cells through rubidium passivation. Chemsuschem. https://doi.org/ 10.1002/cssc.201802690

68. Patil JV, Mali SS, Hong CK (2020) A-site rubidium cation-incorporated $\mathrm{CsPbl}_{2} \mathrm{Br}$ all-inorganic perovskite solar cells exceeding 17\% efficiency. Sol RRL. https://doi.org/10.1002/solr.202000164

69. Hu Y, Aygüler MF, Petrus ML, Bein T, Docampo P (2017) Impact of rubidium and cesium cations on the moisture stability of multiple-cation mixed-halide perovskites. ACS Energy Lett. https://doi.org/10.1021/acsenergylett.7b00731
70. Zhao W, Yao Z, Yu F, Yang D, Liu SF (2018) Alkali metal doping for improved $\mathrm{CH}_{3} \mathrm{NH}_{3} \mathrm{Pbl}_{3}$ perovskite solar cells. Adv Sci. https:// doi.org/10.1002/advs.201700131

71. Tang Z et al (2017) Hysteresis-free perovskite solar cells made of potassium-doped organometal halide perovskite. Sci Rep. https://doi.org/10.1038/s41598-017-12436-x

72. Wang L et al (2020) Potassium-Induced phase stability enables stable and efficient wide-bandgap perovskite solar cells. Sol RRL. https://doi.org/10.1002/solr.202000098

73. Vildanova MF, Nikolskaia AB, Kozlov SS, Karyagina OK, Shevaleevskiy Ol (2020) Potassium doping effect on the photovoltaic performance of perovskite solar cells. Tech Phys Lett 46(3):231-234. https://doi.org/10.1134/S1063785020030153

74. Kim G, Min H, Lee KS, Lee DY, Yoon SM, II Seok S (2020) Impact of strain relaxation on performance of a-formamidinium lead iodide perovskite solar cells. Science. https://doi.org/10.1126/ science.abc4417

75. Stewart RJ, Grieco C, Larsen AV, Maier JJ, Asbury JB (2016) Approaching bulk carrier dynamics in organo-halide perovskite nanocrystalline films by surface passivation. J Phys Chem Lett. https://doi.org/10.1021/acs.jpclett.6b00366

76. Polavarapu L, Nickel B, Feldmann J, Urban AS (2017) Advances in quantum-confined perovskite nanocrystals for optoelectronics. Adv Energy Mater. https://doi.org/10.1002/aenm.20170 0267

77. Li G (2019) Bulk-and nanocrystalline-halide perovskite lightemitting diodes. Adv Nanomater Solar Cells Light Emitt Diodes. https://doi.org/10.1016/B978-0-12-813647-8.00008-4

78. Sharma B, Singh S, Hossain K et al (2020) Additive engineering of 4, 4'-Bis (N-carbazolyl)-1, 1'-biphenyl (CBP) molecules for defects passivation and moisture stability of hybrid perovskite layer. Sol Energy. https://doi.org/10.1016/j.solener.2020.10.035

79. Yang S, Wang Y, Liu P, Cheng YB, Zhao HJ, Yang HG (2016) Functionalization of perovskite thin films with moisture-tolerant molecules. Nat Energy. https://doi.org/10.1038/NENERGY.2015. 16

80. Zhang X, Liu H, Wang $W$ et al (2017) Hybrid perovskite lightemitting diodes based on perovskite nanocrystals with organic-inorganic mixed cations. Adv Mater. https://doi.org/ 10.1002/adma.201606405

81. Kanwat A, Moyen E, Cho S, Jang J (2018) Rubidium as an alternative cation for efficient perovskite light-emitting diodes. ACS Appl Mater Interfaces 10(19):16852-16860. https://doi.org/10. 1021/acsami.8b01292

82. Shi Y et al (2018) Rubidium doping for enhanced performance of highly efficient formamidinium-based perovskite lightemitting diodes. ACS Appl Mater Interfaces 10(11):9849-9857. https://doi.org/10.1021/acsami.8b00079

83. Meng F, Liu X, Cai X, Gong X et al (2019) Incorporation of rubidium cations into blue perovskite quantum dot light-emitting diodes: via FABr-modified multi-cation hot-injection method. Nanoscale 11(3):1295-1303. https://doi.org/10.1039/c8nr0 7907b

84. Todorović $P, M a D$, Chen B et al (2019) Spectrally tunable and stable electroluminescence enabled by rubidium doping of $\mathrm{CsPbBr}_{3}$ nanocrystals. Adv Opt Mater. https://doi.org/10.1002/ adom. 201901440

85. Hoang MT et al (2020) Potassium doping to enhance green photoemission of light-emitting diodes based on $\mathrm{CsPbBr}_{3}$ perovskite nanocrystals. Adv Opt Mater. https://doi.org/10.1002/ adom.202000742

86. Yang JN, Song Y, Yao J et al (2020) Potassium bromide surface passivation on $\mathrm{CsPbl}_{3-\mathrm{x}} \mathrm{Br}_{\mathrm{x}}$ nanocrystals for efficient and stable pure red perovskite light-emitting diodes. J Am Chem Soc. https://doi.org/10.1021/jacs.9b11719 
87. Yang $\mathrm{F}$, Chen $\mathrm{H}$, Zhang R et al (2020) Efficient and spectrally stable blue perovskite light-emitting diodes based on potassium passivated nanocrystals. Adv Funct Mater. https://doi.org/ 10.1002/adfm.201908760

88. Xu B, Wang W, Zhang X et al (2017) Bright and efficient lightemitting diodes based on MA/Cs double cation perovskite nanocrystals. J Mater Chem C 5(25):6123-6128. https://doi. org/10.1039/c7tc01300k

89. Zong Y, Wang N, Zhang L et al (2017) Homogenous alloys of formamidinium lead triiodide and cesium tin triiodide for efficient ideal-bandgap perovskite solar cells. Angew Chemie: Int Ed. https://doi.org/10.1002/anie.201705965

90. Tavakoli MM, Tavakoli R, Prochowicz D, Yadav P, Saliba M (2018) Surface modification of a hole transporting layer for an efficient perovskite solar cell with an enhanced fill factor and stability. Mol Syst Des Eng. https://doi.org/10.1039/c8me00036k

91. Hu Y, Hutter E, Rieder P et al (2018) Perovskite solar cells: understanding the role of cesium and rubidium additives in perovskite solar cells: trap states charge transport, and recombination. Adv Energy Mater. https://doi.org/10.1002/aenm.20187 0073

92. Germino JC, Szostak R, Motti S et al (2020) Postpassivation of multication perovskite with rubidium butyrate. ACS Photonics. https://doi.org/10.1021/acsphotonics.0c00878

93. Yao F, Gui P, Chen C et al (2019) High-rubidium-formamidiniumratio perovskites for high-performance photodetection with enhanced stability. ACS Appl Mater Interfaces. https://doi.org/ 10.1021/acsami.9b12799

94. Amgar D, Binyamin T, Uvarov V, Etgar L (2018) Near ultra-violet to mid-visible band gap tuning of mixed cation $\mathrm{Rb}_{\mathrm{x}} \mathrm{Cs}_{1-\mathrm{x}} \mathrm{PbX}_{3}$ $(\mathrm{X}=\mathrm{Cl}$ or $\mathrm{Br}$ ) perovskite nanoparticles. Nanoscale. https://doi. org/10.1039/c7nr09607k

95. Yang J, Yuan X, Fan L, Zheng Y et al (2021) Enhancing Mn emission of $\mathrm{CsPbCl}_{3}$ perovskite nanocrystals via incorporation of rubidium ions. Mater Res Bull. https://doi.org/10.1016/j.mater resbull.2020.111080

96. Haque MA, Syed A, Akhtar F et al (2019) Giant humidity effect on hybrid halide perovskite microstripes: reversibility and sensing mechanism. ACS Appl Mater Interfaces. https://doi.org/10. 1021/acsami.9b07751

97. Wang Q, Chen B, Liu Y et al (2017) Scaling behavior of moistureinduced grain degradation in polycrystalline hybrid perovskite thin films. Energy Environ Sci. https://doi.org/10.1039/c6ee0 $2941 \mathrm{~h}$

98. Jeong B, Cho S, Cho S et al (2016) Humidity controlled crystallization of thin $\mathrm{CH}_{3} \mathrm{NH}_{3} \mathrm{Pbl}_{3}$ films for high performance perovskite solar cell. Phys Status Solidi: Rapid Res Lett. https://doi.org/ 10.1002/pssr.201600004
99. Yu H, Lu H, Xie F, Zhou S, Zhao N (2016) Native defect-induced hysteresis behavior in organolead iodide perovskite solar cells. Adv Funct Mater. https://doi.org/10.1002/adfm.201504997

100. Tavakoli MM, Saliba M, Yadav P et al (2019) Synergistic crystal and interface engineering for efficient and stable perovskite photovoltaics. Adv Energy Mater. https://doi.org/10.1002/ aenm.201802646

101. Yu W, Li F, Yu et al (2018) Single crystal hybrid perovskite fieldeffect transistors. Nat Commun. https://doi.org/10.1038/ s41467-018-07706-9

102. Yang D, Ming W, Shi H, Zhang L, Du MH (2016) Fast diffusion of native defects and impurities in perovskite solar cell material $\mathrm{CH}_{3} \mathrm{NH}_{3} \mathrm{Pbl}_{3}$. Chem Mater. https://doi.org/10.1021/acs.chemm ater.6b01348

103. Qiao L, Fang WH, Long R, Prezhdo OV (2020) Extending carrier lifetimes in lead halide perovskites with alkali metals by passivating and eliminating halide interstitial defects. Angew Chemie: Int Ed. https://doi.org/10.1002/anie.201911615

104. Liu Y, Pan G, Wang R et al (2018) Considerably enhanced exciton emission of $\mathrm{CsPbCl}_{3}$ perovskite quantum dots by the introduction of potassium and lanthanide ions. Nanoscale. https://doi. org/10.1039/c8nr03581d

105. Ma D, Todorovik $P$, Meshkat $S$ et al (2020) Chloride insertionimmobilization enables bright, narrowband, and stable blueemitting perovskite diodes. ACS Appl Mater Interfaces. https:// doi.org/10.1021/jacs.9b12323

106. Hou S, Gangishetty MK, Quan Q, Congreve DN (2018) Efficient blue and white perovskite light-emitting diodes via manganese doping. Joule. https://doi.org/10.1016/j.joule.2018.08.005

107. Yao EP, Yang Z, Meng L et al (2017) High-brightness blue and white LEDs based on inorganic perovskite nanocrystals and their composites. Adv Mater. https://doi.org/10.1002/adma. 201606859

108. Xing J, Zhao Y, Askerka M et al (2018) Color-stable highly luminescent sky-blue perovskite light-emitting diodes. Nat Commun. https://doi.org/10.1038/s41467-018-05909-8

109. Mir WJ, Sheikh T, Arfin H, Xia Z, Nag A (2020) Lanthanide doping in metal halide perovskite nanocrystals: spectral shifting, quantum cutting and optoelectronic applications. NPG Asia Mater. https://doi.org/10.1038/s41427-019-0192-0

110. Liu W, Lin Q, Li H et al (2016) Mn2 $2^{+}$-doped lead halide perovskite nanocrystals with dual-color emission controlled by halide content. J Am Chem Soc. https://doi.org/10.1021/jacs.6b08085

Publisher's Note Springer Nature remains neutral with regard to jurisdictional claims in published maps and institutional affiliations. 